\title{
Malatya'nın Turizm Potansiyelinin Ortaya Çıkarılmasına Yönelik Algılar
}

\section{Perceptions for the Discovery of Tourism Potential of Malatya}

\author{
İbrahim Atilla Karataş a,* \\ a İnönü Üniversitesi, Sosyal Bilimler Enstitüsü, 44210, Malatya/ Türkiye. \\ ORCID: 0000-0003-4483-0244
}

\section{MAKALE BİLGİSİ}

\section{Makale Geçmişi:}

Başvuru tarihi: 07 Şubat 2017

Düzeltme tarihi: 27 Eylül 2017

Kabul tarihi: 17 Ekim 2017

\section{Anahtar Kelimeler:}

Gastronomi

Destinasyon Pazarlaması

Malatya

\section{ARTICLE INFO}

\section{Article history:}

Received 07 February 2017

Received in revised form 27 September 2017

Accepted 17 October 2017

\section{Keywords:}

Gastronomy

Destination Marketing

Malatya
ÖZ

Turizm sektörünün, yirminci asrın ilk yarısından sonra dünyanın en değerli ve gelir getirici sektörlerinden biri olması hasebiyle ülke politikalarında önemli bir yeri vardır. Türkiye'nin turizm sektörü açısından hak ettiği yere gelebilmesi için özellikle şehirsel mekânların, sahip olduğu değerleri cezbedici bir şekilde hedef kitlelere sunmaları gerekir. İşte bu ahvalde zengin bir tarihsel mirası, kültürü, stratejik konumu, sosyal dokusu ve dinamik ekonomisiyle Malatya ili büyük bir turizm potansiyeline sahiptir. Malatya'nın sahip olduğu değerlerin ortaya çıkartılması ve turizm açısından farkındalık oluşturacak bir şehir konumuna getirilmesi amacı ile hem yerel halka hem de ziyaretçilere yönelik bir anket çalışması yapılmıştır. Anket çalışmasına göre Malatya denilince akla gelen en önemli iki özellik sırası ile kayısı ve gastronomi olmuştur.

\section{A B S T R ACT}

The tourism sector has an important place in the country policies because it is one of the most valuable and revenue generating sectors of the world after the first half of the twentieth century. In order for Turkey to be at the right place in terms of the tourism sector, it is necessary to present especially the urban areas in a way that attracts the values they possess. Malatya province has a great tourism potential with its historical heritage, culture, strategic position, social texture and dynamic economy. Malatya has been carrying out a questionnaire survey aimed at revealing the values it possesses and bringing it into a city that will become aware of tourism in terms of both local people and visitors. According to the questionnaire survey, the two most important features that come to mind in Malatya are apricot and gastronomy.

\section{Giriş}

Turizm olgusu dünyada ve ülkemizde ekonomik katkılarının yanı sıra sosyal ve kültürel boyutuyla başlı başına bir sektör olarak kendini kabul ettirmiştir. Turizm değerlerini misafirlerine sunma bilgi ve yeteneğine sahip şehirler, bölgeler ve ülkeler ekonominin diğer sektörleriyle karşılaştırıldığında çok az maliyet isteyen yatırımlarla büyük paralar kazanmaktadırlar. Turizm, gelişmişlik düzeyine bakılmaksızın tüm ülkeler için vazgeçilmez bir sektör hâline gelerek ülkeler arasında kıyasıya bir rekabet yaşanmasına neden olmuştur. Turizm sektöründe "yatırım maliyetikazanç" ilişkisi, diğer sektörlerle karşılaştırılamayacak oranda kazanç lehinedir (Gezer vd., 2013: 33). Turizm gelirlerinden sadece turisti o ülkeye getiren seyahat acenteleri veya konaklama tesisleri yararlanmamakta, çok sayıda sektör bu gelirden pay almaktadır.

Geçmişten günümüze şehirler, farklı yerlerden gelen insanlar tarafından iş, alışveriş ve benzeri diğer nedenlerden dolayı her zaman ziyaret edilmişlerdir. 1950'li yıllara kadar yabancı şehirlere seyahat, nüfusun küçük bir bölümü ile sınırlı kalırken; 1980'li yıllardan itibaren şehirler, ekonomilerini canlandırmak ve şiddetli rekabet koşullarına karşılık verebilmek için turistik tesislere, kurumsal mekânlara ve ekonomik faaliyetleri geliştiren etkinliklere yönelik yatırımlarını arttırmaya başlamışlardır. $\mathrm{Bu}$ anlamda şehirlerin sahip oldukları zenginlikleri bir farkındalık oluşturacak şekilde hedef kitlelere sunmaları turistik faaliyetleri, cezbedici bir şekilde etkilemektedir.

\footnotetext{
* Sorumlu yazar/Corresponding author.

e-posta: ibrahimatillakaratas@gmail.com
} 
$\mathrm{Bu}$ çalışmada amaç yerel halk ve ziyaretçiler açısından Malatya'nın turizm potansiyelinin ortaya çıkarılmasında destinasyon marka imaj değerlerinin etkileri nelerdir? sorusuna cevap bulmaktır. Destinasyon Pazarlaması ile ilgili daha önce yapılmış olan bazı yayınlara bakıldığında aşağıdaki etkenlerin öne çıktığı görülmektedir. Vatan (2015), "Destinasyon Pazarlaması Kapsamında Bilecik İli Turizminin Değerlendirilmesine Yönelik Paydaş Analizi” adlı doktora tez çalışmasında; destinasyonun etkin bir şekilde pazarlanması için şehrin tüm paydaşlarının iş birliği içinde olmalarının önemini ifade etmiştir. Ceylan (2010), "Yerel Kalkınma ve Rekabet Aracı Olarak Şehir Pazarlamasında Yatırımcıların Yatırım Destinasyon Tercih Yapılarının Belirlenmesi ve Uşak Tekstil Sektöründe Bir Uygulama" adlı doktora tez çalışmasında; şehir pazarlamasındaki aktörlerin ortak bir paydada buluşmasının gerekli olduğunu belirtmiştir. Akçi ve Uluışık (2016), "Marka Şehir Oluşturma: Şehirde Oturanların Değerlendirmeleri Üzerine Bir Uygulama(Adıyaman Örneği)" adlı makale çalışmasında; şehir pazarlamasında olumlu imaj faktörünün uzun süreli bir süreci gerektiren ve tüm paydaşların katılımı ile etkinliğini artıran büyük bir etkiye sahip olduğunu belirtmişlerdir. Rainisto (2003), "Destinasyon Pazarlamasının Başarı Faktörleri: Kuzey Avrupa ve ABD'de Destinasyon Pazarlaması Üzerine Bir Uygulama", adlı doktora tez çalışmasında; şehir pazarlamasında başarının sağlanması için stratejik planlama, organizasyon, örgütlenme ve ölçüm-takip işlerinin öneminden bahsederek kamu ve özel sektör imkânlarının birleştirilmesinin gerekliliğini ifade etmiştir. Miličević (2016), "Rekabet Unsuru Olarak Bir Destinasyonun Markalaşması" adlı doktora tez çalışmasında; destinasyon markasının güçlü bir rekabet avantajına sahip olması için, destinasyon ile potansiyel ziyaretçiler arasında duygusal bir bağın oluşturulması gerektiğini ifade etmiştir.

Hoang (2010), "Şehir Planlama ve Yer Pazarlama Modeli: Viet Nam'daki Şehirler ve Bölgeler Üzerine Bir Uygulama" adlı doktora tez çalışmasında; şehir pazarlamasında başarılı olabilecek modelleri oluşturup uygulayabilmek için kurumsal temelde ve ulusal kanunlar alanında etkin reformların şart olduğunu ifade etmiştir. Demirovic (2016), "Bir Turizm Destinasyonu Olarak Hersek'in Marka Değer Oluşumu" adlı yüksek lisans tez çalışmasında; marka şehir oluşumunun bir süreç meselesi olduğunu belirtmiştir. Süreci profesyonel bir ekibin uzun dönemli stratejik planlar hazırlayarak, şehrin paydaşları ile uyum içinde yönetmesi gerektiğini ifade etmiştir.

$\mathrm{Bu}$ çalışmanın benzerlerinden farkı yerel halk ve ziyaretçilerden oluşan farklı iki grubun destinasyon pazarlanmasında sorulara verdikleri cevapların benzer ve farklı yönlerinin şehrin turizm potansiyelinin belirlenmesi üzerindeki etkilerini ortaya koymaktır. $\mathrm{Bu}$ çalışmada Malatya ilinin seçilmesinin nedeni Malatya'nın Türkiye'nin doğusunda yer alan stratejik öneme sahip önemli şehirlerden biri olmasıdır. Ayrıca Malatya önemli iş merkezlerinden biri olma yolunda ilerlemektedir. Tarih boyunca pek çok medeniyete ev sahipliği yapan Malatya, zengin bir tarihe ve zengin mutfak kültürüne sahiptir. Aynı zamanda destinasyon marka imaj çalışmalarında, Malatya'nın bu önemli değerlerinin etkin bir şekilde kullanılmadığı da düşünülmektedir.

\section{Malatya'nın Tarihî, Mimarî ve Kültürel Yapısı}

Doğu Anadolu Bölgesi'ndeki Fırat Havzası'nın yukarı bölümünde yer alan Malatya'nın, doğusunda Diyarbakır ve Elazı̆̆, batısında Kahramanmaraş, kuzeyinde Erzincan ve Sivas, güneyinde ise Adıyaman şehri bulunmaktadır. Malatya İl Yönetim Alanı toplam olarak $12.412 \mathrm{~km}^{2}$ olup bu alanın matematiksel konumu $35^{\circ} 34^{\prime}$ ve $39^{\circ} 03^{\prime}$ kuzey paralelleri ile $38^{\circ} 45^{\prime}$ ve $39^{\circ} 08^{\prime}$ doğu meridyenleri arasındadır. Malatya Büyükşehir sınırları; Battalgazi ve Yeşilyurt merkez ilçeleri ile birlikte toplam 13 ilçe ve bunlara bağlı mahalle yerleşmelerinden oluşmaktadır (Malatya Valiliği, 2014: 3). İl genelinde bulunan toplam nüfus miktarı 31 Aralık 2016 tarihi itibarıyla 781.305 kişidir. Bu nüfus miktarını belirleyen 304.397 kişi merkez Battalgazi ilçesinde, 304.369 kişi ise merkez Yeşilyurt ilçesinde yaşamaktadır. Malatya, ülkedeki 81 şehir arasında nüfus itibarı ile 27. sırada yer almaktadır (TÜİK, 2016a). Malatya, isim olarak Kültepe belgelerinde Melita, Hitit belgelerinde Maldia, Asur Imparatorluk devri belgelerinde ise Meliddu, Melide, Melid, Melissa olarak geçer. Urartu belgelerinde ise ismi Melita'dır. Malatya kelimesi Hititçe "bal" manasındaki “melid”den türemiştir (Tuğrulca, 2013a: 29).

\subsection{Milattan Önce Malatya}

Malatya'da ilk şehir yerleşmelerinin MÖ (7000) ile MÖ (2000) yılları arasında Tohma Çayı ve Fırat kenarında (Cafer Höyük, Değirmentepe höyük, Pirot Höyük, İmikuşağı Höyük, Habibuşağı Höyük gibi) ortaya çıktığı görülmektedir. İklim özellikleri, orman alanlarının genişliğ̣i, ekilebilir arazi durumu ve Firat nehrinin sağladığı su yolu taşımacılığının bu yerleşim yerlerinin oluşmasında önemli etkisi olmuştur. Ekilebilir arazilerden elde edilen artık ürünlerin, orman ürünlerinin ve yer altı madenlerinin (özellikle demir madeninin) suyolu taşımacılığı ile Fırat ve Dicle kenarlarında kurulmuş Mezopotamya'daki şehirlere ulaştırıldığı bilinmektedir (Tuğrulca, 2013a: 33).

Malatya, Orta Asya'dan ve Orta Doğu Mezopotamya'dan gelen ticaret yollarının birleştiği ve batıya bağlantı sağlayan bir mevkide olması nedeni ile her dönemde stratejik bir önem arz etmiştir. İlk çağın ilk ticaret yolu olan Ege kıyılarını Mezopotamya'ya bağlayan meşhur Kral Yolu'nun ve Çin'den Batı'ya uzanan tarihî İpek Yolu'nun güneye inen bir kolunun da geçtiği yer olan Malatya; Hitit, Asur, Pers, Roma, Bizans, İslam, Selçuklar, Osmanlı ve Cumhuriyet Devri uygarlıklarının tümünde önemli bir stratejik geçiş ve ticaret merkezi konumunda olmuş ve birçok ülke arasında sık sık el değiştiren bir şehir olmuştur (Aytaç, 2015: 8). 1979 senesinde Karakaya Baraj Gölü'ünde İzollu mevkii Cafer Höyük’te kazılar yapılmıştır (Malatya Valiliği, 2011: 2). Bu kazılarda yöre insanlarının MÖ önce 7000 yılında ilk kez hayvancılık ve tarımla iştigal ettikleri, yerleşik hayata girdikleri ve bu yerleşik hayatın Aslantepe, Değirmentepe, İsa Höyük ve Firıncı Höyük'te de MÖ 5000-3000 y1lları arasında da sürdüğü anlaşılmaktadır. Hitit, Asur, Medler ve Perslerin hâkimiyetine giren şehir MÖ 4. asırda Anadolu'yu ele geçiren Büyük İskender'in etkisi ile Helenistik kültürün tesirinde kalmıştır (Sayım, 2007: 10). 
Şekil 1. Furat Vadisindeki Yerleşkeler, Malatya

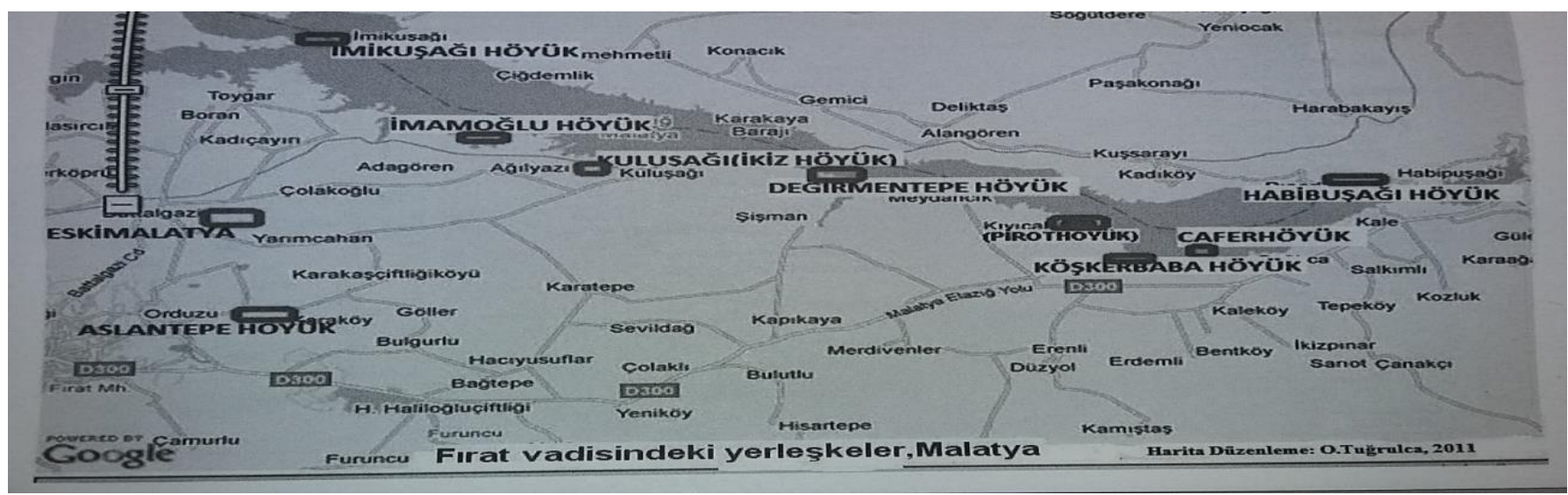

Kaynak: Tuğrulca (2013a: 113).

\subsection{Roma ve Bizans Döneminde Malatya}

"Malatya" adı Romalıların bölgeye gelişine kadar bugün Aslantepe olarak bilinen yerleşke için ifade edilmiştir. Aslantepe yerleşkesi MS 100 yıllarına kadar da ana yerleşke olarak varlığını sürdürmüştür. Romalılar miladi ilk yüzyılın içerisinde şehri bugün Battalgazi olarak bilinen Eski Malatya'ya taşımışlardır (Tuğrulca, 2013a: 29). Battalgazi'ye MS 79-81 y1llarında Roma Kralı Titus zamanında 12. Fulmineta Lejyonu'nun daimi karargâhı taşınmıştır. Tekrar şehre bu dönemde "Melitene" denmiştir. Artık bu andan başlayarak şehir ismi olarak bu isim kullanılmaya başlanacaktır (Malatya Belediyesi, 2015a: 13).

Romalılar tarafindan önceleri askeri bir garnizon şehir olarak tasarlanmış olan Malatya (Melitene) zamanla nüfusunun artmasından dolayı daimi yerleşim yeri hâline dönüşmüştür (Tuğrulca, 2013a: 169). Bizanslılar döneminde özellikle Justinyanus (MS 527-565) zamanında Malatya bir eyalet merkezi hâline getirilmiştir (Sayım, 2007: 10). Roma İmparatorluğu zamanında yapılmaya başlayan surlar, İmparator Justinyanus döneminde 532 yılında tamamlanmış ve şehir 536 yılında III. Armenia eyaletine merkez olmuştur. Siyasal ve askerî merkez haline gelen Melitine, ayrıca kilise kayıtlarında Metropolis diye anılmasından da anlaşılacağı üzere yörenin dini merkezi haline gelmiştir. Bizans'in Anadolu'daki toprakları arasında stratejik bir mevkide bulunan şehir, MS birinci ve altıncı yüzyıllar arasında, bilhassa Sasani İmparatorluğu'na yönelik olarak sınır kalesi pozisyonundadır (Gökalp, 2009: 218).

Bizanslılar, Malatya'yı Romalılardan daha çok geliştirmişlerdir. Bizanslılar şehir surlarını onarmış ve sağlamlaştırmışlardır. Bostanbaşı, Gündüzbey, Yakınca, Yeşilyurt, Tecde, Banazı gibi yerleşim alanları Bizanslılar tarafindan inşa edilmiştir. Şehrin ihtiyaç duyduğu su, bugünkü gibi Derme Suyu olarak da adlandırılan Gündüzbey'deki su kaynaklarından tedarik edilmiștir (Malatya Valiliği, 2004: 6). Bizans kralı Jüstinyen, şehri Sasani İmparatorluğu'na karşı stratejik bir savunma merkezi olarak gördüğünden şehre azami oranda önem atfetmiştir (Sayım, 2007: 10).

\subsection{Arap ve Türk Medeniyetleri Döneminde Malatya}

Malatya, İslam halifesi Hz. Ömer (632-642) zamanında ilk defa Müslüman Araplar tarafından fethedilmiş, (639) fakat uzunca bir zaman Müslüman Araplar ile Bizanslılar arasında el değiştirmiştir. Malatya'nın stratejik konum olarak yolların kesiştiği noktada ve önem arz eden dağ geçitleri arasında olması, Arapların bu şehre özel ilgi göstermelerini sağlamıştır (Malatya Valiliği, 2004: 6). Bizans kaynaklarında 'Melitene' olarak geçen şehrin adını Araplar 'Malatiyye' olarak zikretmişlerdir (Malatya Büyük Şehir Belediyesi, 2015a: 13).

Türkmen boyları tarafından Anadolu'da başlatılan fetih hareketlerinin sonunda 1057 ve 1085 y1lları arasında kısa süreli olarak Selçuklular tarafından ele geçirilen Malatya, 18 Eylül 1101'de Türkler tarafından alınmıştır. 1399 yılında Yıldırım Beyazıt zamanında Osmanlı topraklarına katılan Malatya, Timur'un istilasının ardından Dulkadiroğulları Beyliği'nin topraklarına dâhil olmuştur. Malatya, 1516 senesinde Yavuz Sultan Selim zamanında Osmanlı topraklarına katılmıştır. $\mathrm{Bu}$ tarihten itibaren günümüzdeki haline kadar büyüyüp gelişimini devam ettirmiştir. Bizanslılar ve Araplar arasında sık sik el değiştirip harap edilen, bunun için de surlar içine alınan "Eski Malatya" bugünkü Battalgazi ilçe merkezinden, 1838 yılında günümüzdeki yerine (Aspuzu Bağları Bölgesi) yerleşmiştir (Çiçek, 2011: 29).

Aspuzu Bağları bölgesine yerleşmede etkili olan olay, 18381839 Osmanlı-Mısır Savaşları esnasında yaşanmıştır. Hafız Mehmet Paşa, Osmanlı ordusunu Eski Malatya içindeki evlere yerleştirmiştir. Yaz aylarını her sene bağlar bölgesi olarak anılan "Aspuzu"da geçiren halk, yaz sonunda şehre inememiş ve kışı da burada geçirmiştir. Tarihinde üçüncü kez yer değiştirme yaşayan Malatya'nın yerlileri için bu durum onların sürekli yerleşim yerini tayin eden bir gelişme olmuştur (Karabacak, 2013: 346).

On dokuzuncu asırda parçalanma dönemini yaşamaya başlayan Osmanlı İmparatorluğu toprakları, I. Dünya Savaşını izleyen yıllarda gizli ve aşikâr olarak Batılı sömürge güçleri eli ile bölüşülmüştür. Savaş sonrasında sömürge güçleri Anadolu'daki toprakları kendi aralarında paylaşırlarken Malatya'yı, Fransız hâkimiyeti altına verdikleri görülmektedir. Bu paylaşım yapılmış olsa da Malatya düşman işgaline uğramamış şehirlerarasındadır. Osmanlı İmparatorluğu'nun hayatta kalma savaşı yaptığı o yıllarda Malatya halkı kendinden beklenen görevi ifa etmiştir (Gezer vd., 2011: 24). 
Şekil 2. Malatya'nın Şehirleşme Öyküsü

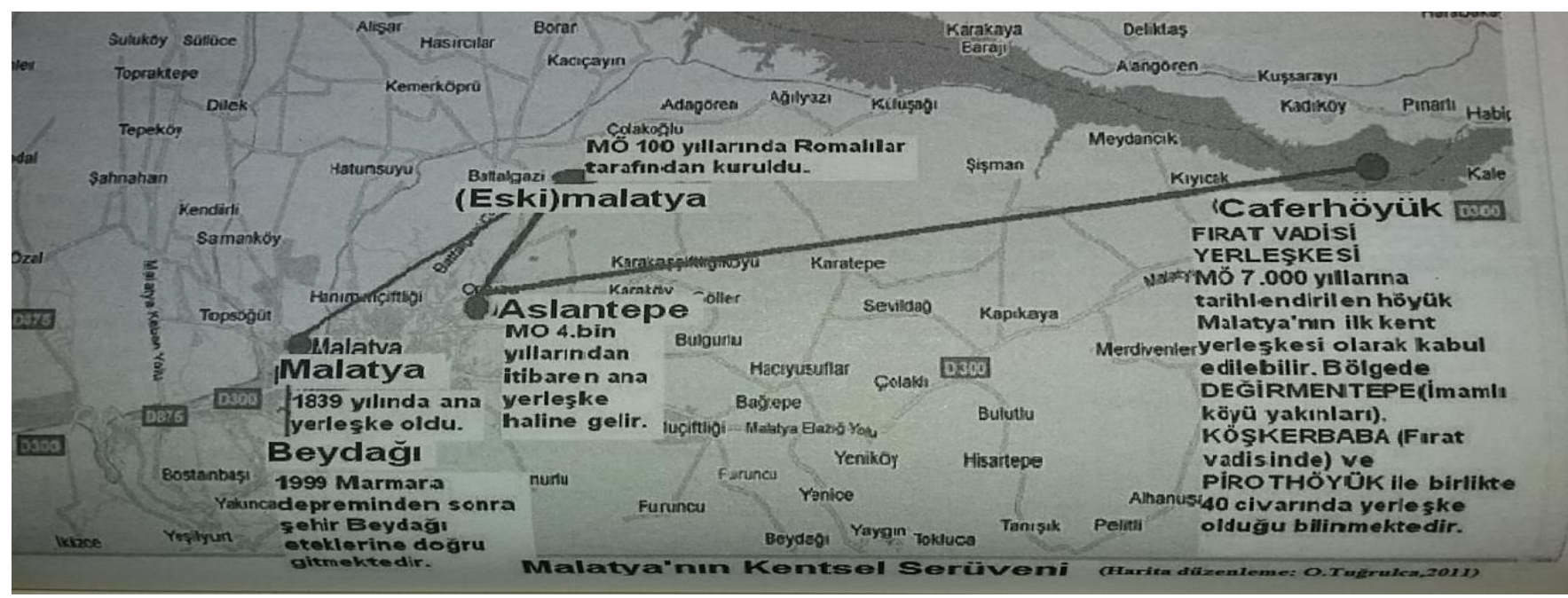

Kaynak: Tuğrulca (2013a: 29).

1878 yılında Elazığ'ın (Mamuretü'l-Aziz) Diyarbakır'dan ayrılıp vilayet olması üzerine Malatya sancağı bu vilayete bağlanmıştır. 1920 yılında müstakil sancak hâline gelen Malatya, 1924 yılında vilayet olarak teşkilatlanmıştır (Tuğrulca, 2013c: 103-104). Şehir için cumhuriyetin ilanından sonra 1930'larda kapsamlı bir planlama ve kanalizasyon çalışması gerçekleştirilmiştir. Cumhuriyet döneminde Malatya şehrinin ilk imar planları 1933'lere gelindiğinde tamamlanmıştır (Yenen, 1939: 125). Malatya, mimarlık açısından en zengin devirlerini Selçuklular zamanında yaşamış; kervansaraylar, han ve hamamlar, camiler bu devirde yapılmıştır. Malatya şehir merkezinin kuruluş tarihinin yeni oluşu sebebi ile günümüze ulaşan evlerin çoğunluğu 1880 ile 1950 yılları arasında inşa edilmiştir (Aytaç, 2015: 9-11).

Malatya'da 1950'li yıllardan itibaren başlamış olan şehirleşme hareketi, bilhassa o dönemde kurulmaya başlayan bazı sanayi sektörlerinin (1938 -Sümerbank, 1956-Şeker Fabrikası, 1957-Tekel, 1975-Vagon Onarım Fabrikası, 1974-Et Kombinası gibi) kurulmasını da hızlandırmıştır. Daha sonraki dönemde 2. Ordu Komutanlığı'nın Malatya'ya taşınması, 1975 yılında İnönü Üniversitesi'nin kurulması, bazı kurumların Bölge Müdürlüklerinin inşa edilmesi, iplik ve dokuma tesislerinin kurulması, kayısı işleme kurumlarının açılması, un-bulgur imalathanelerinin faaliyete geçmesi, kereste ve mobilya imalathanelerinin ve Organize Sanayi Bölgesi'nde bulunan ticaret, sanayi ve hizmet dallarının gelişmesi ile şehirleşme süregelmiştir. Bu esnada Karakaya Barajı göl sahası altındaki yerleşim bölgelerinde bulunan nüfusun oldukça büyük bir kısmı göç ederek Malatya'ya yerleşmiştir. Bu değişimlerin akabinde Malatya, sosyo-ekonomik verilere göre Türkiye ortalamasının oldukça üstünde bir seviyeye yükselmiştir (Sever, 2008: 67). Malatya Belediyesi 06/12/2012 tarihli 28489 sayı ile resmi gazetede yayımlanan 6360 sayılı kanunla Büyükşehir olmuştur (Malatya Büyükşehir Belediyesi, 2015b: 14).

\section{Malatya'nın Turistik Yapısı}

Turizm sektörünün, yirminci asrın ilk yarısından sonra dünyanın en değerli ve gelir getirici sektörlerinden biri olması hasebiyle ülke politikalarında önemli bir yeri vardır. İç ve uluslararası turizmde 1950'lerden bu yana meydana gelen büyüme, 1950 'de 25 milyon olan uluslararası turist gelişinin 2010'da 935 milyona çıkmasıyla dramatik bir artış göstermiştir (İlker, 2012: 101). Bu artış Birleşmiş Milletler Dünya Turizm Örgütü raporuna göre 2016 yılı sonunda 1 milyar 235 milyona ulaşmıştır (UNWTO, 2017).

Zengin bir tarihsel mirası, kültürü, altyapı olanakları, ulaşım avantaj1, sosyal dokusu ve dinamik ekonomisiyle Malatya ili büyük bir turizm potansiyeline sahiptir. İl merkezindeki potansiyel değerlerden biri olan Arkeoloji Müzesi'nde, Aslantepe ve Karakaya Baraj Gölü altında kalan höyüklerle diğer höyüklerde yapılan kazılarda bulunan eserler sergilenmektedir.

İl turizmine büyük katkısı olan diğer turistik yerler, sinema caddesindeki sivil mimari değeri olan ahşap Beş Konaklar, şehir meydanındaki Yeni Cami ile Bakırcılar Çarşısı, Kuru Kayısı Pazarı yabancı turistlerin alışveriş merkezi durumundadır (Malatya Valiliği, 2011: 162).

Malatya'nın Pütürge kazası Tepehan çevresi üzerinden varılan Nemrut ile Eski Malatya, Aslantepe ve Arkeoloji Müzesi’nde yer alan yapıtlar kültür turizminin zenginliği olarak ilgi uyandırır. Levent Vadisi, Karakaya Barajı ve Sultansuyu ise Malatya'nın ortaya çıkarılmayı bekleyen doğa turizmi hazineleridir. Torosların devamındaki Beydağları'nın kuşattığı Malatya'yı büklümlerle ayıran akarsular ve dağ eteklerinden gelen memba sularının çokluğu, o civarda meyve bahçelerinin ve ova içerisinde yeşilliğin yaygınlaşmasını sağlamıştır. İşte Malatya'nın bu doğal güzelliği ve tarihsel dokusu, turizm açısından çekiciliğini artırmaktadır (Malatya Büyükşehir Belediyesi, 2015b: 13).

Dağ ve tabiat turizmi olarak ilgi çekici natürel değerler arasında Darende ilçesinde Tohma Çayı doğal vadisi, natürel akvaryum, Somuncu Baba Boğazı, Günpınar Şelalesi, Doğanşehir kazasında Sulu Mağara, şehrin içinde İnderesi Mağaraları, Yazıhan'da Buzluk Mağaraları, Battalgazi'de Karakaya Baraj Gölü sıralanabilir. Karakaya Baraj Gölü su sporları yönünden spor turizminde göz önünde tutulabilecek alanlardandır. Akçadağ'da bulunan Sultansuyu Harası ise atla tabiat yürüyüşlerinin gerçekleştirilebildiği bir alandır. Malatya, av turizmi ve balıkçılık açısından elverişlidir. Toprağın üzerinde keklik avcılığı, Arapgir ve Pütürge kazalarında yaban domuzu ve tavşan avcılığı; Fırat Irmak'1, Tohma Çayı ve Karakaya Baraj Gölü'nde balıkçılık yapılır. 
İnanç turizmi açısından Nemrut Dağı Millî Parkı, Taşhoron Kilisesi, Venk Kilisesi, Malatya il merkezinde Yusuf Ziya Paşa Camii, Battalgazi'de Ulu Cami, Yeni Cami, Darende'de Şeyh Hamid-i Veli Zaviyesi (Somuncu Baba Türbesi ve Camii) önemi olan mekânlardır. Kültürle ilgili ve tarihî cazibeler içerisinde İstanbulluoğlu Konağı, Gazi İlkokulu binası, Orduzu mevkiinde Aslantepe Höyüğü, Eski Malatya'da bulunan Silahtar Mustafa Paşa Kervansarayı, Hasan Basri (Korucuk) Türbesi kale surları ve Namazgâh sayılabilir (Gök ve Tuna, 2013: 3).

Malatya'da Kültür ve Turizm Bakanlığı'ndan işletme belgeli tesisler(Otel) sayısı on yedidir. Bunların üçü beş yıldızlı, beși dört yıldızlı, yedisi üç yıldızlı, ikisi iki yıldızlı olup toplam 1294 oda ve 2569 yatak kapasitesine sahiptir. Aynı şekilde belediye belgeli otel sayıs1 14 olup; 341 oda ve 689 yatak kapasitesine sahiptir (Malatya Valiliği Turistik Tesisler, 2016). Malatya'da belediye belgeli ve turizm işletme belgeli tesisler dikkate alındığında yıllara göre şehre gelen yabancı turist sayısı Şekil 3'te gösterilmiştir.

Şekil 3. Malatya'da Belediye Belgeli ve Turizm İşletme Belgeli Tesislere Geliş Sayısı (Yabancı Turistler)

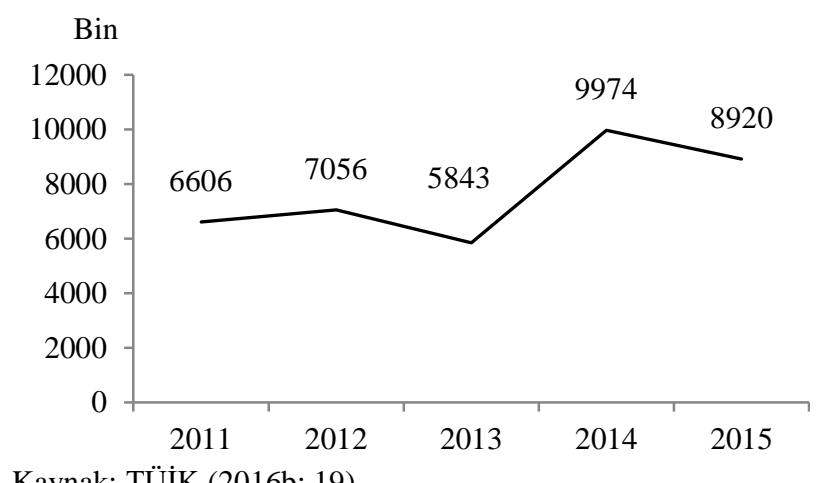

4. Malatya'nın İklim Tarım ve Hayvancılık Yapısı

Firat Havzasında yer alan Malatya, denizden yüksekliği yaklaşı1k 900 m'dir. Kış mevsiminde yağışı ve soğuk, yaz mevsiminde sıcak ve yağışsız olan iklimi vardır. Malatya, Güney Doğu Anadolu karasal iklimi, Akdeniz yağıș rejimi ve Doğu Anadolu karasal iç bölge yağış rejimi aralarında bir intikal yeridir. Bu bağlamda Malatya'nın iklimi, karasal ve Akdeniz iklimi arasında bir mikro klimadır. Bu nitelik değișik iklimlere ait çok fazla ürünün Malatya'da kolaylıkla yetiştirilmesini sağlamaktadır (Gezer vd., 2011: 25-49).

Malatya'da tarım arazilerinin \%59,25'inde kuru; \%40,75'inde suyla ziraat yapılır. Sulanma imkânı bulunan bağ bahçe arazisinin hatırı sayılır kısmında da kayısı yetiştiriciliği yapılmaktadır (Malatya Valiliği, 2014: 3). Tarihî kaynaklarda Türkistan, Orta Asya ve Batı Çin nahiyelerinin kayısının ana vatanı olduğu zannedilmektedir. Belgelerden aktarılanları göz önüne aldığımızda kayısı, Büyük İskender'in doğu seferi sırasında (MÖ IV. yy.) Anadolu'yla tanıştırılmıştır. Anadolu'da 2000 seneyi geçkin bir zamandır kayısı üretildiği sanılıyor. İlerleyen süreçte Malatya bu üretimde Türkiye'de ve dünyada ilk sırada olmuştur (Malatya Valiliği, 2013: 12).

Kayısıdan sonra elma, üzüm, armut, dut, ceviz ve kiraz gelir. 1655 yillında Malatya'ya ulaşan meşhur gezgin Evliya Çelebi 53 bin insanın bulunduğu ilde 7.800 meyve bahçesi ve 7 kayısı türünden söz eder. Kayısı üretimi olarak en önemli yerler: Darende, Akçadağ, Battalgazi, Kale, Merkez, Yazıhan ve Hekimhan'dır. Malatya kayısı üretimi, Türkiye yaş kayısı üretiminin tahmini olarak \%50-55'ini; kuru kayısı üretiminin ise \%85'ini oluşturmaktadır (Ünal, 2010: 11).

Malatya'nın dünya yaş kayısı üretiminde yaklaşık \%11'lik; kuru kayısı üretiminde ise \%70'lik bir payı vardır. Yine de kayısı üretiminde önemli bir payı olan Malatya, piyasa fiyatlarını belirleyememektedir. 15 yıl içinde 100 milyon dolardan 300 milyon doları bulan kayısı ihracat değerinin, kuvvetli bir ihracatçı birlikteliğinin meydana getirilmesi, ürün ve paket çeşitliliğinin oluşturulması, soğuk zincir yatırımlarıyla taze kayısı ihracatına da önem verilmesi ve ihracatçılar arasında var olan hukuki ilişkinin yeniden düzenlenmesi sonucunda orta vadede 1 milyar dolarlık seviyeye ulaşabileceği varsayılmaktadır (Ünal, 2010: 27). Malatya'da 50.000 ailenin geçinme kaynağı kayısıdır. Bu, hemen hemen 250.000 nüfusa tekabül edip nüfusun tamamının yaklaşık \%33'ünü karşılamaktadır. Kayısının rekoltesi ve ihracat miktarı arasında fiyat açısından aynı oranda bir paylaşım yoktur. Bunun başta gelen müsebbipleri, ihracat izleminin eksikliği ve ihracatçıların birlik sağlayamamasıdır. Yeni pazar yerlerinin olmaması, iç tüketimin sağlanamayışı ve var olan rekoltenin piyasaya göre dengelenememesi arz-talep uyumunu negatif olarak etkilemektedir. $\mathrm{Bu}$ nedenledir ki ürünün ihracat rakamları temel alınarak $\mathrm{kg}$ fiyatlarında bir devamlılık oluşturulamamıştır. Tablo 1'de bu durum açık bir şekilde ifade edilmektedir (Malatya Ticaret ve Sanayi Odas1, 2014: 8).

Tablo 1. Kayısı İhracat Miktarları

\begin{tabular}{cccc}
\hline Yillar & $\begin{array}{c}\text { İhraç Edilen } \\
\text { Miktar } \\
\text { (Ton) }\end{array}$ & $\begin{array}{c}\text { İhracat Getirisi } \\
(\$-\text { Usd) }\end{array}$ & $\begin{array}{c}\text { 1 Kg Kuru } \\
\text { Kay1s1 İhraç } \\
\text { Tutar1 }(\$ / K g)\end{array}$ \\
\hline 2011 & 89.751 & 364.938 .201 & 4.06 \\
2012 & 101.540 & 298.301 .477 & 2.94 \\
2013 & 117.861 & 315.263 .534 & 2.67 \\
2014 & 79.043 & 348.184 .876 & 4.40 \\
2015 & 76.570 & 32.198 .000 & 4.20 \\
\hline
\end{tabular}

Kaynak: (TUİK,2016 $6_{\mathrm{c}}$

Tablo 1'de görüldüğü üzere, son 5 y1l içinde kg başına en düşük fiyat 2.67 \$ ile 2013 yılında; en yüksek fiyat ise 4.40 \$ ile 2014 senelerinde elde edilmiştir. Bunun yanında 2013 senesinde 117.861 ton ile kayısı ihracat rakamiyla yukarılarda olmasına karşın 315.263.534 \$ ihracat geliri oluşmuş ve 2.67 \$/ton girdisi ile ton başına en düşük ihracat değerini elde etmiştir. 2011 ise 364.938.201 \$ ile son 5 senenin kayısıda en yüksek döviz girdisinin sağlandığı yıl olmuştur.

Malatya'da her sene takriben 100 bin ton kuru kayısı üretilip ihraç yapılmakta ve bundan aşağı yukarı 250-300 milyon dolar döviz girdisi elde edilmektedir. Malatya'da 50 dolaylarındaki kayısı işleme tesisinde aşağı yukarı 5.000 kişi istihdam edilmektedir. Diğer yandan, 300'e yakın esnaf ve tüccar ile 50'ye yakın ihracatçı da kayısı işletmecisidir. Yine Malatya'da 10'a yakın firma kayısı makineleri imalatı yapmaktadır. Türkiye yaş kayısı üretimi, senelere göre büyük dalgalanma göstermekle beraber üretimde yükseliş eğilimi sürmektedir (Ünal, 2010: 30).

2010-2015 yılları arasında yaş kayısı üretimi yıllara göre Şekil 4'te olduğu gibidir. Hava şartlarındaki sıra dışı değişimler kayısı üretimini büyük oranda etkilemektedir. 
Şekil 4. Yıllara Göre Malatya Yaş Kayısı Üretimi (Ton)

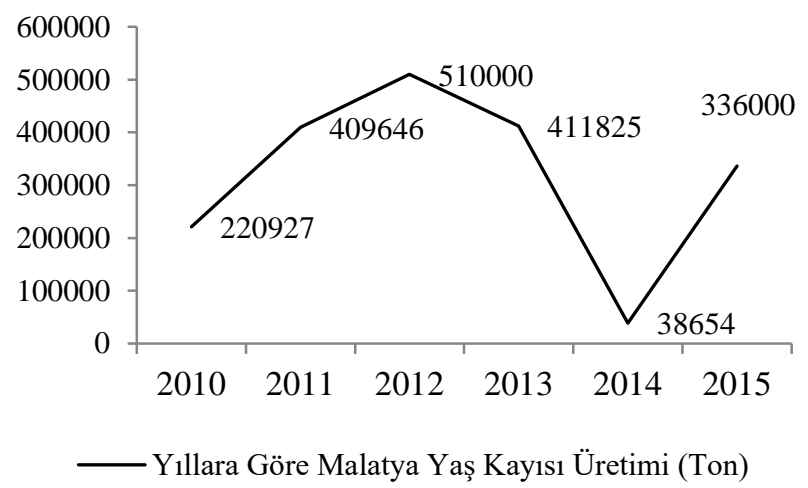

Kaynak: TÜİK (2016b: 30)

Tarımsal çalışmaların mühim bir kolu olan hayvancılık, dünya üzerinde kırsal kesimdeki insanların uğraştıkları bir alandır. Türkiye'de kırsal uğraşı düzeni içinde genellikle tarımsal çalışmaların yanında ikinci derecede kendine yer bulan hayvancilık, ek bir getiridir. Ancak, hayvancılık çalışmaları bilhassa dağlık toprak yapısına sahip kırsal yerlerde öne çıkarak en başlarda yer alabilir. Yakın zamanlara kadar bir tarım ülkesi olarak değerlendirilen Türkiye'de hayvancılık hem hayvansal ürünlerden (et, süt, deri, yumurta, tarlalara gübre, yakacak olarak tezek vb.) hem de kuvvetinden (yük taşıma, tarla sürme, ulaşım aracı olarak) yararlanmak gayesiyle devam ettirilmiştir. Bugün de artan nüfusun beslenmesinde ve sanayiye hammadde sağlanmasında (yünlü; ipekli dokuma; deri, kösele vb.) önemli olan hayvancılık, ulusal ekonomimizin \%20'sini meydana getirmiştir (Ertin, 1998: 137).

Şekil 5. Malatya ve Civar İllerin Büyükbaş ve Küçükbaş Hayvan Sayıları (2014 Yılı)

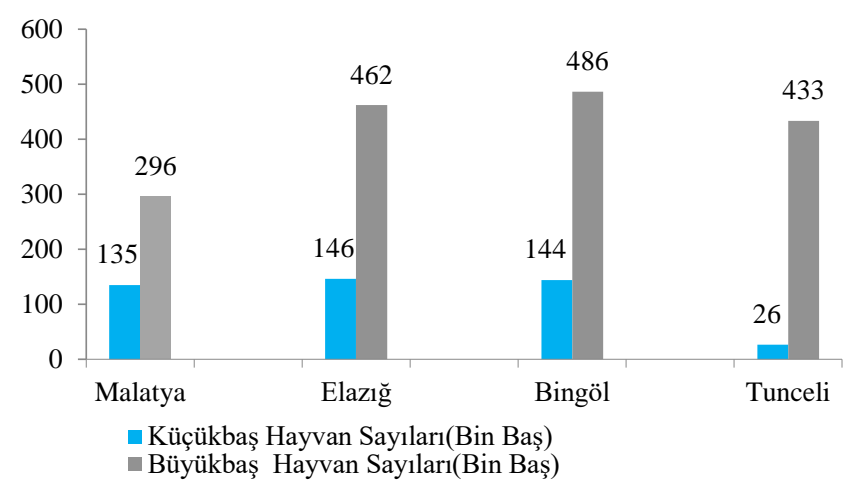

Kaynak: TÜİK (2015: 45).

Şekil 5'te Malatya'nın hayvancılıkla ilgili verileri çevre illerle karşılaştırıldığında düşük kaldığı görülmektedir. Malatya, tarıma ayrılan topraklarının büyüklüğü ve verimliliği ile aynı zamanda çayır ve mera olarak kullanılan alanların Türkiye ortalamasının üzerinde olmasından dolayı etkin bir hayvanc1lı politikası sayesinde ileri bir seviyeye ulaşabilir.

\section{Malatya'nın Eğitim Hizmetleri Yapısı}

Bilginin çok hızlı değiştiği 21. asırda her ülkenin dünya üzerinde etkin bir şekilde yer alabilmesi, oluşturduğu toplumun bireylerinin beraber ve uyum içinde yaşamlarını sürdürmeleri ve gereken ortak davranışların elde edilebilmesi için iyi eğitim almış nüfus kitlesine sahip olması gerekir. Hakikaten dünya savaşlarından mağlup olan Japonya ve Almanya benzeri ülkeler eğitim düzeyi yüksek ve nitelikli bir nüfusları olduğundan çok az bir vakitte yeniden ayağa kalkmış toplumlara en güzel iki misaldir (Akbulut, 2010: 116). Şekil 6'da Malatya'nın eğitim düzeyi ile Türkiye eğitim düzeyi ortalaması verilerine bakıldığında, Malatya'daki eğitim yapısı hemen hemen Türkiye ortalaması ile örtüşmektedir.

Şekil 6. 2014 Yılı Verilerine Göre Malatya'daki Eğitim Durumu ve Türkiye Ortalaması (\%).

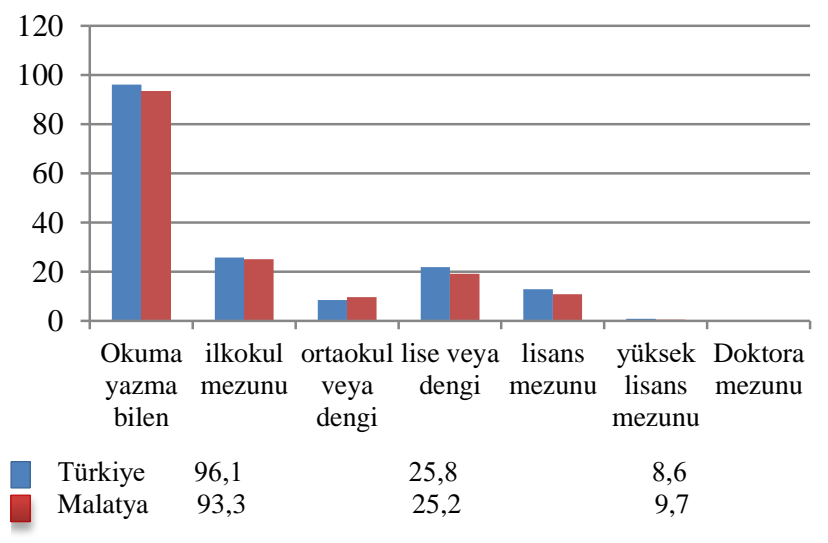

Kaynak: TÜİK (2016b:12)

2014-2015 eğitim-öğretim yılında kişi başına düşen öğretmen sayısı Türkiye genelinde ilkokulda 18, ortaokulda 17, lisede 14 iken; Malatya'da kişi başına düşen öğretmen sayısı ilkokulda 15, ortaokulda 13, lisede 14 olarak gerçekleşmiştir (TÜİK, 2015: 10).

Malatya'da 1975 senesinde kurulan İnönü Üniversitesi 13 fakültesi 1'i Devlet Konservatuvarı olmak üzere 4 yüksekokulu, 12 meslek yüksekokulu, 5 enstitüsü, 1 teknokenti, Turgut Özal Tıp Merkezi'nin dahi içinde yer aldığ 19 araştırma ve uygulama merkeziyle takriben 30.000 öğrenciye eğitim ve öğretim veren bir üniversitedir. 2'si şehir merkezinde 4'ü kazalarda toplamda 6 yerleşkesinde eğitim-öğretim, bilimsel araştırma ve uygulama çalışmalarını sürdürerek bölgenin ve Türkiye'nin eğitim hayatına katkı sağlamaktadır (İnönü Üniversitesi, 2015).

\section{Malatya'nın Ticari ve Sanayi Yapısı}

Malatya, sanayileşme yönünden ülkemizin en arkalarda bulunan Doğu Anadolu bölgesindedir. Ancak daha sonraki sanayileşme gayreti ile bulunduğu yerin sanayileşme açısından öndeki şehirlerinden olmuştur. Malatya 1 . Organize Sanayi Bölgesi 1976 senesinde kurulmuş ancak türlü nedenlerle 1984'e kadar pek ilerleyiş kaydedilememiştir. Bu yıldan sonra çalışmalar hız kazanmış ve 1986 yılında hizmete girmiştir (Çiçek, 2011: 102).

Organize Sanayi Bölgesi’ndeki firmaların ağırlıklı olarak \%27'lik oranla gida sektöründe yoğunlaştığı görülmektedir. G1da sektörünü \%23 oranı ile tekstil izlemektedir.

Bu sektörleri $\% 5$ 'lik oran ile plastik, orman ürünleri, inşaat ve sanayi takip etmektedir. Malatya 2. Organize Sanayi Bölgesi ise 1997 yılında 160 parsellik bir kapasite ile kurulmuştur. Burada üretime geçen firma açısından sektörel dağılıma bakıldığında \%41 ile gida ilk sırada yer almakta; onu, \%19 ile tekstil, \%15 ile makine-yedek parça 
izlemektedir (Malatya Ticaret ve Sanayi Odası, 2014: 1112).

Malatya'nın 2013 verileri göz önüne alındığında iş gücüne katılım oranında $\% 54,1$ ile Türkiye genelinde 25 , isssizlik oranında $\% 7,8$ ile 37 , istihdam oranında $\% 49,90$ ile 21 . sırada bulunmaktadır. Malatya'nın son üç yıl ortalamasında iş gücüne katılma oranı $\% 50,47$; işsizlik oranı $\% 7,93$; istihdam oranı ise \%46,50'dir. Yani Malatya il ölçeğinde son üç yılda iş gücüne katılma ve istihdam oranlarında net artış olmamasına rağmen işsizlik oranında da büyük bir artış görülmemektedir (Malatya Ticaret ve Sanayi Odası, 2014: 7). Şekil 7'de Malatya'nın ihraç ürünlerine bakıldığında tarım sektörünün ilk üç sıralamayı oluşturduğu ortaya çıktığı görülmektedir.

Şekil 7. 2015 Yılı Malatya'dan İhraç Edilen Ürünler

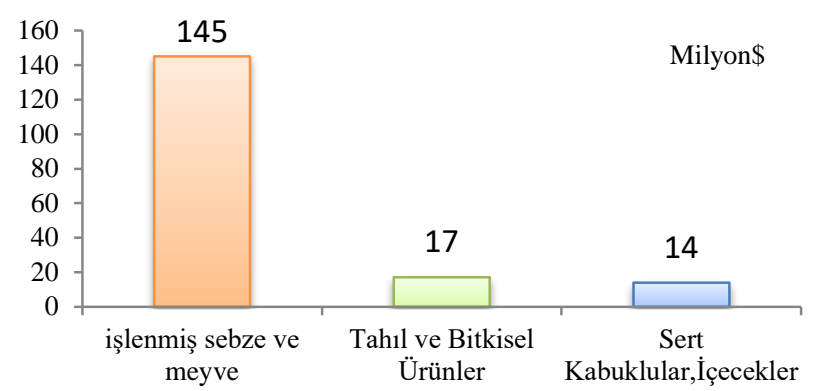

Kaynak: TÜİK (2016b: 46)

Malatya'nın en fazla ihracat yaptı̆̆ı ülkeler sıralamasında ise $\% 35$ ile ABD, \%22,7 ile Irak ve \%17 ile Almanya'yı görmekteyiz (TÜIK, 2016b: 44). Malatya Ticaret Odas1 kayıtlarına göre toplam 950 şirkette takriben 28.500 kiși çalışmaktadır. Malatya'da sırasıyla gıda, tekstil ve inşaat sektörleri hem istihdam sayısı hem de şirket sayısı olarak öne çıkmaktadır (Malatya Ticaret ve Sanayi Odası, 2014: 8).

\section{Malatya'nın Lojistik Yapısı}

Malatya, eski zamanlardan beri önemli yol güzergâhındadır. Malatya, Basra'dan gelip Sivas ve Tokat'tan Samsun'a kadar giden ve Malatya'dan ayrılarak Darende, Gürün üzerinden Kayseri'ye ve buradan da batıya doğru uzanan yolların birleştiği mekândadır (Karagöz, 2013: 10). Mezopotamya ile Anadolu arasındaki ticaret ve kültür alışverişinin bu yol aracılığıyla yapılması Malatya'yı önemli hale getirmiştir (Başıüyük, 2015: 29). Bununla birlikte, Kafkaslardan veya Karadeniz'den gelip Misır'a giden yollar da Malatya'dan geçmektedir. Malatya'nın etrafindaki yerleşim bölgeleriyle irtibatını kuran yollar üzerinde bulunan kervansaray ve hanlar, Selçuklu ve Osmanlı döneminde şehrin ticari öneminin tanıkları olan ve Malatya'nın tarih içerisindeki ticari olanaklarına tanıklık eden ticari yerlerdir (Karagöz, 2013: 10).

\section{Malatya'nın Sağlık Hizmetleri Yapısı}

Ülkemizde sağlik turizmi bilhassa 2003'te başlayan “sağlıkta dönüşüm programı" ile gelişim göstermiştir. Sağlık Bakanlığı'nın eşgüdümünde özel ile kamu sektörü arasında iş birliği yapılması sağlık turizminin etkinliğini artırmıştır. Sağllk turizminde ilk beş ülke Hindistan, Tayland, Singapur, Amerika Birleşik Devletleri ve Malezya'dır. Malezya ve Singapur'da sağllk turizmi Türkiye'de olduğu gibi devlet desteğiyle özel sektör-devlet iş birliği eşgüdümünde gelişim göstermiştir. Asya ülkeleri, uluslararası kuruluşlarca onaylanan sağlık tesislerine ve kaliteli sağlık çalışanlarına sahip olmaları, fiyatlarının uygunluğu, bir beklemenin olmayışı, üstün teknolojiye sahip oluşları ve bireysel sağlık hizmeti sunmaları ile seçilir hâle gelmişlerdir. Turistlere sağlanan vize imkânı da bir diğer faktördür. Türkiye' de aynı biçimde birçok ülke ile vize sözleşmesi yapmakta ve bu sözleşmeler sağlık turistlerine vize rahatlığı sağlamaktadır. Sağlık turizminde bir ülkenin gelişmesinin ön şartlarından biri de ülkedeki siyasi ve sosyal durumun çalkantılı olmayışıdır. Malezya ve Singapur gibi Asya ülkeleri siyasi ve sosyal devamlılık nedeniyle de yeğ tutulmaktadır. $\mathrm{Bu}$ anlamda Türkiye'nin sağlık turizminde amaçlarına erişebilmesi için siyasi ve sosyal devamlılığ yerine getirmesi gerekir (Aslonova, 2013: 131-141).

Toplumda yaşayan bütün fertleri ilgilendiren en önemli faktörler, kesinlikle güvenli ve orijinal bir sağlık hizmeti imkânına erişmektir. Bugün sosyal refah anlayışını kabul eden devletler, temel insan haklarından sağlık hizmetlerini tüm topluma dinamik, faydalı ve ihtiyaçları karşılayan bir seviyede sunabilmek ya da zaruri tedbirleri sağlamakla yükümlüdür (Çağlar ve Gülel, 2015: 31). Bazı sağlık verileri açısından Malatya ile Türkiye ortalaması Tablo 2'de gösterilmiştir. İki veri arasında paralellik görülmektedir.

Malatya İnönü Üniversitesi Turgut Özal Tip Merkezi, 1200 yataklı büyük bir hastane olarak hizmet vermektedir. Tıp merkezi, karaciğer naklinde Avrupa birincisi ve dünya ikincisi olmayı başarmış bir hastanedir. Karaciğer nakli olmadığında yaşama şansını kaybeden yüzlerce kişi, İnönü Üniversitesi'ndeki bu tıp merkezi sayesinde yaşama dönmektedir. Karaciğer nakil ameliyatlarındaki başarı oranı yüzde 83 olan tıp merkezi 2013 yılında 1000'inci karaciğer naklini gerçekleştirmiştir (Ergu, 2013). Malatya İnönü Üniversitesi Turgut Özal Tip Merkezi, bölgenin ve Türkiye'nin tercih edilen ve sağlık turizmi açısından önemli olan bir merkezi hâline gelmiştir (Tatar vd.,2011).

\section{Malatya'nın Gastronomi Hizmetleri Yapısı}

Gastronomi turizmi sanayisi, yalnız yemek rehberlerinden ve restoranlardan oluşmamaktadır. Her çeşit mutfak tecrübelerini de içerisine alır. Bu sektörde aşçllk mektepleri, gastronomi tur operatörleri, yemek kitapları satan dükkânlar, tur rehberleri, gastronomi ile ilgili medya, televizyon programları ve dergiler, gastronomi ile ilgili etkinlikler, tarla sahipleri ile üreticiler bulunmaktadır (Çağlı, 2012: 24).

16.yüzyılda Anadolu'yu ziyarete gelen ünlü zengin Dernschwam, yazılarında Türklerin baş yemeğinin çorba olduğunu belirtir. $\mathrm{Bu}$ zenginlik Malatya mutfağına da yansımışıtır. Malatya'da 30'dan fazla çorba hâlen yapılarak sofralarda yer almaktadır. Bunlardan bazıları şunlardır: Ayva köfteli kulak çorbası, bulama çorba, ezme yoğurt çorbası, gendime çorbası, irinti çorbası, kelle paça, malhuta çorbası, maş çorbası, pirpirim çorbası, mercimekli erişte çorbası, sütlü aş çorbası, tarhana çorbası, yoğurtlu gendime çorbası (soğuk çorba), yüksük çorbası gibi. Özellikle içerisinde kara nohut, 1spanak, kavurma, yoğurt, nane ve tereyağı gibi malzemeler bulunan Malatya usulü tarhana çorbası kış aylarında grip, nezle gibi hastalıklara yakalananlara ilaç niyetine içirilen bir çorbadır. 
Tablo 2. Başlıca Sağlık Verileri Açısından Malatya İli İle Türkiye Ortalaması

\begin{tabular}{|c|c|c|c|c|c|c|c|c|c|}
\hline İl Ad1 & $\begin{array}{c}\text { Hastane } \\
\text { Say1s1 }\end{array}$ & Yatak Sayısı & $\begin{array}{c}10.000 \text { Kişiye } \\
\text { Düşen Yatak } \\
\text { Sayısı }\end{array}$ & $\begin{array}{l}\text { Yoğun } \\
\text { Bakım } \\
\text { Yatağ1 } \\
\text { Sayıs1 }\end{array}$ & $\begin{array}{c}\text { Aile } \\
\text { Hekimliği } \\
\text { Birimi Sayısı }\end{array}$ & $\begin{array}{l}\text { Aile Hekimi } \\
\text { Başına Düssen } \\
\text { Nüfus }\end{array}$ & $\begin{array}{c}112 \\
\text { İstasyon } \\
\text { Say1s1 }\end{array}$ & $\begin{array}{c}112 \\
\text { Ambulans } \\
\text { Say1s1 }\end{array}$ & $\begin{array}{c}112 \text { Ambulans } \\
\text { Başına Düşen } \\
\text { Nüfus }\end{array}$ \\
\hline Malatya & 19 & 2713 & 35,1 & 504 & 220 & 3513 & 31 & 64 & 12.077 \\
\hline Türkiye Ort. & 19 & 2588 & 26,6 & 389 & 267 & 3629 & 28 & 52 & 18.584 \\
\hline İl Ad1 & $\begin{array}{l}\text { Uzman } \\
\text { Hekim }\end{array}$ & $\begin{array}{c}\text { Pratisyen } \\
\text { Hekim }\end{array}$ & $\begin{array}{c}\text { Asistan } \\
\text { Hekim } \\
\end{array}$ & $\begin{array}{l}\text { Toplam } \\
\text { Hekim }\end{array}$ & Diş Hekimi & Eczac1 & Hemşire & Ebe & $\begin{array}{c}\text { Diğer Sağlik } \\
\text { Personeli }\end{array}$ \\
\hline Malatya & 797 & 458 & 299 & 1554 & 206 & 248 & 1995 & 876 & 1913 \\
\hline Türkiye Ort. & 958 & 516 & 269 & 1743 & 306 & 339 & 1886 & 655 & 1801 \\
\hline
\end{tabular}

Kaynak: Sağlık Bakanlığı (2015)

Malatya otuzdan fazla çorba kültürüne sahipken şehirde birçok lokantada çorba olarak mercimek, ezogelin ve yayla çorbaları sunumu yapılmaktadır. Ancak son yıllarda yöresel yemek yapan işletmelerin, ziyaretçilerine zengin Malatya çorbalarını sunmaları önemli bir gelişmedir (Kılıç, 2016: 60).

Malatya'daki yerel gastronomi etkinlikleri Yeşilyurt Kiraz Kültür ve Spor Şenliği, Uluslararası Kültür, Sanat ve Kayısı Festivali, Malatya Fuarı ve Arapgir Bağbozumu'dur. Ayrıca Akçadağ Belediyesi Bal, Armut, Kültür ve Sanat Festivali ile Doğanşehir Elma ve Kültür Şenliğidir (Çağl1, 2012: 82). Malatya'nın tescil almış ürünleri Arapgir Köhnü Üzümü ve Malatya kayısısıdır (Çağlı, 2012: 67).

\section{Malatya'nın İnsan Faktörü Yapısı}

Malatya, yüzyıllara, kavimlere, gelip geçen pek çok medeniyete, birçok olaya ev sahipliği yapmış, çağına şahitlik etmiş bir şehir olarak bilinir. Malatya, Mezopotamya sınırında bulunmasından dolayı Doğu-Batı kültürünü sentezleyen bir atölye gibi siyasetten sanata birçok ünlü yetiştirmiştir. Sosyoloji alanında önemli çalışmaları bulunan Orhan Türkdoğan'a göre Malatya'da pek çok ünlünün yetişmesinin sebeplerinden biri şehrin "Baharat Yolu" üzerinde bulunmasıdır. Ona göre burada doğan insanlar kendilerini tabii olarak bir kültür iklimi içinde bulmaktadır (Başıüyük, 2014: 10-11).

Osmanlı döneminde Malatya'nın önde gelen yetişmiş insanları arasında sayabileceğimiz bazı isimler şunlardır (Tuğrulca, 2013b: 357):

- Yusuf Kamil Paşa (1808-1876), Malatya'nın Arapkir ilçesinde doğmuştur. Ticaret nazırlığı ve 1863 yılında 5 ay süre ile sadrazamlık (başbakanlık) yapmıştır.

- Şeyhülislam Arif Hikmet (1786-1859), 1845 y1lında Osmanlı devletinin 105. şeyhülislamı olmuş ve bu görevi 7 y1l sürdürmüştür. Sultan Abdülmecit (1839-1861), Arif Hikmet Bey'in şeyhülislamlığa tayinini bildiren yazıda, onun faziletlerinden bahsetmiştir.

- Osman Nuri Ergin (1882-1961), bir eğitimci olarak Türk eğitim tarihinin gün yüzüne çıarılmasında, belediyecilik ve şehircilik tarihinde önemli bir yere sahiptir.

Niyazi-i Misrî (1618-1694), Türk tasavvuf şiirinin Yunus Emre'den sonraki önemli mümessillerindendir. Tasavvufi görüşleriyle yaşadığı çağın ötesine geçebilmiş bir sufi olan Misrî Hazretleri, Osmanlı Devleti'nin yöneticilerinin de ilgisini çekmiştir (Doğan ve Çelik, 2015: 147).

Cumhuriyet dönemi sonrasında da Malatya; siyaset, sanat ve bilim alanında önemli şahsiyetlerin yetişmesine vesile olmuştur. Bunlardan bazıları şunlardır:
- İsmet İnönü (1884-1973), Türkiye Cumhuriyetinin ilk başbakanı ve 2. cumhurbaşkanıdır. Malatya'nın ekonomik gelişimine katkı sağlayan bazı sanayi tesislerinin kurulmasına öncülük yapmıştır (Başıbüyük, 2015: 119).

- Turgut Özal (1927-1993), teknik bürokrat olarak Başbakanlık Teknik Müşavirliği ve DPT Müsteşarlığı görevlerinde bulunmanın yanında bir dönem Dünya Bankasında çalışmıştır. 1983'te Anavatan Partisini kurarak siyasete giren Özal, Cumhuriyet'in 19. başbakanı olarak 13 Aralık 1983-21 Aralık 1987 tarihleri arasında 45, 21 Aralık 1987-09 Kasım 1989 tarihleri arasında 46. hükümeti kurmuştur. 1989 tarihinde Türkiye Cumhuriyetinin 8. cumhurbaşkanı olduktan sonra ölümüne kadar bu görevini sürdürmüştür (Kesriklioğlu ve Çiftlikçi, 2011: 34). Özal, Türkiye'nin dinamiklerini harekete geçirerek liberal ekonominin, liberal düşüncenin, serbest rekabetin, insanların yeteneklerinin ve daha fazla demokrasinin önünü açan bir lider olarak tarihe damgasını vurmuştur (Kesriklioğlu ve Çiftlikçi, 2011: 72).

- Ahmet Kaya (1957-2000), sözleri ve ezgilerindeki farklı tarzı ile tanınmış bir ses sanatçısıdır (Başıbüyük, 2015: 132).

Kemal Sunal (1944-2000), Türk güldürü sinemasında bir ekol olan, güldürürken düşündüren, düşündürürken de güldüren, halkın beğenisini kazanmış bir sinema sanatçısıdır (Taş, 2011: 8).

11. Malatya'da Yaşayan Yerli Halk ile Malatya'yı Ziyaret Eden Yerli Turistlere Şehrin Sahip Olduğu Turistik Değerlerin Ortaya Çıkarılmasına Yönelik Algıları ile İlgili Yapılan Araştırma

Malatya'nın sahip olduğu turistik değerlerin ortaya çıkarılmasına yönelik yapılan araştırma ile ilgili değerlendirmeler bu bölümde ele alınmıştır.

\subsection{Araştırmanın Konusu}

Araştırmanın konusu Malatya'da yaşayan yerel halk ile Malatya'yı ziyaret eden yerli turistlerin Malatya'nın turizm potansiyelinin ortaya çıkarılması ile ilgili algılarının belirlenmesidir. Bunun için anket hazırlanarak cevaplayıcılara açık uçlu sorular sorulmuştur.

\subsection{Araştırmanın Önemi}

Çalışmanın önemi hem ziyaretçilerin hem yerel halkın (iş dünyası, ev hanımı, emekli, çalışan, öğrenci vs.) şehrin turizm potansiyelinin ortaya çıkarılması ile algılarının ele alınmış olmasıdır. Turistik değerlerin bu algılar üzerinden 
yürütülmesi ile etkin bir destinasyon pazarlama yapısının gerçekleşeceği düşünülmektedir.

\subsection{Araştırmanın Amacı, Kapsamı ve Sınırları}

Yirminci yüzyılın ikinci yarısından itibaren genel olarak dünyada şehirleşme oranının artması ile beraber şehrin sorunlarına çözümler üretebilmek ve hedef kitlelere dünya standartlarında hizmetler sunabilmek için farklı öneriler üzerinde durulmaktadır. Mal veya hizmet pazarlamasında, ürün marka imajı ne kadar önemli ise bir destinasyon pazarlamasında da destinasyon imajının o kadar önemi vardır. Bu durumda destinasyon pazarlamasında başarılı olmak için, destinasyon imajının incelenmesi gerekir. Bu doğrultuda destinasyon imaj algısı hem yerel halk hem de ziyaretçiler açısından ele alınmıştır.

Araştırma, Malatya ili merkez ilçelerinde (Yeşilyurt, Battalgazi) gerçekleştirilmiştir. Malatya il sınırları içindeki bütün yerleşim yerlerine ulaşmak zaman ve maliyet açısından mümkün görülmediğinden bu durum araştırma yönünden sınırlılık olarak görülebilir. . Ayrıca sadece Türkiye'den bir ile yönelik olması tüm örneklemi temsil etme gücünün zayıf olduğunu ve diğer illere ve Türkiye'ye genelleyemeyeceğini göstermektedir.

Örneklem büyüklüğünün hesaplanmasından önce, evrenin tespit edilmesi için Malatya'yı ziyaret eden turist sayıları belirlenmiştir. Buna göre 2015 y1lında 147.633 kişi Malatya'yı ziyaret etmiştir (Yatırım ve İşletmeler Genel Müdürlüğü, 2016). Örneklem yapılırken pazarlama alanında en çok kullanılan \% 95 güven aralığı ve \% 5 hata sınırları olan örneklem büyüklüğü ele alınmıştır. Bu örneklem büyüklüğü literatürde 384 kişidir (Cohen vd., 2007). Çalışmada 400 kişinin üzerinde anket çalışması yapılması öngörülmüştür. Yapılmış olan anketlerde yüz yüze görüşme yöntemi kullanılmıştır. Araştırmada ziyaretçiler için örneklem hacmi 410 olarak belirlenmiştir. Örneklem sayısının belirlenmesinde Tesadüfi Örnekleme Yöntemi içerisinde yer alan Kümelere Göre Örnekleme Yöntemi esas alınarak 20 küme tespit edilip, bunların içerisinden Basit Tesadüfü Örnekleme yöntemi ile 9 küme seçilmiştir. Bu mekânlar; Havaalanı, Gar, Otobüs Terminali, Malatya Alışveriş Merkezi, Şire Pazar'1, Anemon Otel, Avşar Otel, Kırçuval Otel ve Mentalite Otel'dir. Anket uygulaması 7 17 Ekim 2016 tarihleri arasında yapılmıştır.

Yerel halk araştırmasında kullanılan yöntem, Tesadüfi Örnekleme Yöntemi içerisinde yer alan Kümelere Göre Örnekleme yöntemidir. Yerel halk evrenini Malatya'nın merkez iki ilçesinde (Battalgazi-Yeşilyurt) yaşayan halk oluşturmaktadır. Türkiye İstatistik Kurumu'na ait resmi internet sitesinde (TUIK, 2016d) yayınlanan verilere göre bu iki ilçenin 2015 yılı itibariyle nüfusları Battalgazi ilçesinde, 304.397 kişi, Yeşilyurt ilçesinde 304.369 kişi olarak belirlenmiştir. Örneklem sayısının belirlenmesinde Tesadüfî Örnekleme Yöntemi içerisinde yer alan Kümelere Göre Örnekleme Yöntemi uygulanmıştır. Bu yönteme göre ana kütleyi meydana getiren birim belirli bir coğrafi alanı kapsıyorsa ana kütleyi oluşturan eşit düzeydeki alt bölge örnekleri içinden bir veya birkaçı tesadüfü olarak seçildikten sonra anket uygulaması için seçilen bu alt bölge örneklerinden yine aynı şekilde bir veya birkaçının tesadüfi olarak seçilmesini temel alan bir yöntemdir (Nakip, 2006: 2015). Bu yönteme göre Battalgazi ve Yeşilyurt ilçeleri mahallelere bölündükten sonra aynı șekilde caddelere de bölünmüştür. Mahalle ve caddelerin belirlenmesinde bütün mahalle ve sokak isimleri yazılarak önce mahalleler ardından caddelerin tespiti Basit Tesadüfi Örnekleme yöntemi baz alınarak gerçekleştirilmiştir (Kurtuluş,1985:218). Bu dokuz caddenin isimleri ise; Tecde Mahallesi-Yeşilyurt Caddesi, Bostanbaşı Mahallesi-Bahçelievler Caddesi, Samanlı Mahallesi-Fahri Kayahan Bulvarı, Cumhuriyet Mahallesi100.yıl Caddesi, Çavuşoğlu Mahallesi-5.Cadde, Başharık Mahallesi-Mehmet Akif Ersoy Caddesi, Zafer MahallesiSağlık Caddesi, Yıldıztepe Mahallesi-Hilaltepe Caddesi ve Bulgurlu Mahallesi-İnönü Üniversitesi'dir. Anket 15-25 Ekim 2016 tarihinde uygulanmıştır.

Örneklem yapılırken pazarlama alanında en çok kullanılan $\% 95$ güven aralığ 1 ve $\% 5$ hata payındaki örneklem büyüklüğü dikkate alınmıştır. Bu örnekleme göre sayı literatürde 384 kişidir (Cohen vd.,2007; Burns ve Bush, 2015). Çalışmamızda 400 kişinin üzerinde anket çalışması yapılması öngörülmüştür. Anketi cevaplayan 443 kişinin formları incelendiğinde 428 kişinin verdiği cevapların usulüne uygun olduğu tespit edilip değerlendirmeye alınmıştır.

\section{Bulgular}

Malatya'da yaşayan yerli halk ile Malatya'yı ziyaret eden yerli turistlere şehrin sahip olduğu turistik değerlerin ortaya çıkarılmasına yönelik algıları ile ilgili yapılan araştırmanın demografik özelliklerine göre dağılımı Tablo 3 ve Tablo 4 'te ifade edilmiştir.

Tablo 3. Yerel Halkın Demografik Özelliklerine Göre Dağılımı

\begin{tabular}{|c|c|c|}
\hline $\begin{array}{l}\text { Ankete Katılan } \\
\text { Kişi Sayısı } \\
\end{array}$ & $\begin{array}{c}428 \\
\text { Kişi Sayısı(n) } \\
\end{array}$ & $\begin{array}{c}\text { Yüzde } \\
(\%)\end{array}$ \\
\hline \multicolumn{3}{|l|}{ Cinsiyet } \\
\hline Erkek & 243 & 56,8 \\
\hline Kadın & 185 & 43,2 \\
\hline \multicolumn{3}{|l|}{ Yaş } \\
\hline $18-25$ yaş arası & 153 & 35,7 \\
\hline $26-35$ yaş arası & 125 & 29,2 \\
\hline $36-45$ yaş arası & 97 & 22,7 \\
\hline 46-55 yaş arası & 35 & 8,2 \\
\hline 56-65 yaş arası & 8 & 1,9 \\
\hline 66 ve üzeri & 10 & 2,3 \\
\hline \multicolumn{3}{|l|}{ Eğitim Durumu } \\
\hline İlköğretim & 59 & 13,8 \\
\hline Lise & 113 & 26,4 \\
\hline Üniversite & 232 & 54,2 \\
\hline Yüksek Lisans & 22 & 5,1 \\
\hline Doktora & 2 & 0,5 \\
\hline \multicolumn{3}{|l|}{ Medeni Durum } \\
\hline Evli & 230 & 53,7 \\
\hline Bekâr & 198 & 46,3 \\
\hline \multicolumn{3}{|l|}{ Aylık Gelir } \\
\hline 2000'e kadar & 227 & 53 \\
\hline $2001-4000$ aras1 & 158 & 36,9 \\
\hline 4001-6000 aras1 & 28 & 6,5 \\
\hline $6001-8000$ aras1 & 6 & 1,4 \\
\hline 8001 ve yukarıs1 & 9 & 2,1 \\
\hline
\end{tabular}


Anket çalışmasına katılan yerel halkın demografik yapısı analiz edildiğinde büyük bir kısmının 18 ile 45 yaş aralığında $(\% 87,6)$, lise ve üniversite düzeyinde eğitim aldığ $1 \% 80,6)$, medeni durum ve cinsiyet olarak ortalama bir dağılım gösterdiği, aylık gelir olarak çoğunluğun ortalama düzeyin altında $(\% 53)$, büyük bir bölümünün de $(\% 43,4)$ orta düzey (2001-6000 TL) sınırları içerisinde bir gelire sahip olduğu bir yapı ortaya çıkmaktadır.

Tablo 4. Ziyaretçilerin Demografik Özelliklerine Göre Dağılımı

\begin{tabular}{lcc}
\hline $\begin{array}{l}\text { Ankete Katılan } \\
\text { Kişi Sayısı }\end{array}$ & $\begin{array}{c}410 \\
\text { Kişi Sayısı(n) }\end{array}$ & $\begin{array}{c}\text { Yüzde } \\
(\%)\end{array}$ \\
\hline Cinsiyet & & \\
\hline Erkek & 200 & 48,8 \\
Kadın & 210 & 51,2 \\
\hline Yaş & & \\
\hline 18-25 yaş arası & 174 & 42,4 \\
26-35 yaş arası & 95 & 23,2 \\
36-45 yaş arası & 97 & 23,7 \\
46-55 yaş arası & 28 & 6,8 \\
56-65 yaş arası & 12 & 2,9 \\
66 ve üzeri & 4 & 1,0 \\
\hline Eğitim Durumu & & \\
\hline İlköğretim & 76 & 18,5 \\
Lise & 90 & 22,0 \\
Üniversite & 220 & 53,7 \\
Yüksek Lisans & 19 & 4,6 \\
Doktora & 5 & 1,2 \\
\hline Medeni Durum & & \\
\hline Evli & 192 & 46,8 \\
Bekâr & 216 & 52,7 \\
Cevapsız & 2618,7 \\
\hline Aylık Gelir & & \\
\hline 2000'e kadar & & \\
2001-4000 arası & & \\
\hline & & \\
\hline
\end{tabular}

Anket çalışmasına iştirak eden ziyaretçilerin demografik yapısı analiz edildiğinde ise büyük bir kısmının 18 ile 45 yaş aralığında $(\% 89,3)$ lise ve üniversite düzeyinde eğitim aldığ 1 $(\% 75,7)$ medeni durum ve cinsiyet olarak ortalama bir dağllım gösterdiği, aylık gelir olarak çoğunluğun ortalama düzeyin altında $(\% 63,7)$ bir gelire sahip olduğu, belli bir bölümünün de (\% 32.2) orta düzey (2001-6000 TL) bir gelire sahip olduğu görülmüştür. Malatya'ya sık sık gelen ve esas geliş amacı eş/dost ziyareti, kültür gezisi ya da farklı nedenlerle olan bir yapı ortaya çıkmaktadır. Malatya, kongre ve iş turizmine yönelik gelişmekte olan istikrarlı bir bölge içinde olmasına rağmen ziyaretçilerden az bir bölümü $(\% 7,3)$ toplantı için ya da seminer amacıyla şehre geldiğini bildirmiştir. Kongre ve toplantı turizmi potansiyelini arttırmak için kongre ve iş turizmini teşvik edecek atılımların yapılması (altyapı, bina, iletişim ve haberleşme) önem arz etmektedir.

Araştırma veri anketi hazırlanırken yerel halk ve ziyaretçilere Malatya denilince sırası ile akla gelen ilk üç şeyin ne olduğu ve Malatya’yı bölgedeki diğer illerden farklı kılan ilk üç şeyin ne olduğu sorusu sorulmuştur.
Analiz sonucunda yerel halka göre, Malatya denilince ilk sırada akla gelen özellik kayısı $(\% 82,1)$, ikinci sırada yemek $(\% 8,7)$ üçüncü sırada ise misafirperverlik $(\% 7,4)$ olmuştur. Ziyaretçilere sorulan aynı sorulara verilen cevaplar değerlendirildiğinde akla gelen ilk şey kayısı (\%80,7), ikinci sırada yemek $(\% 9,7)$ üçüncü sırada ise siyasetçi $(\% 8,6)$ izlemektedir. Günlük yaşam içinde kayısı Malatya ile bütünleşmiş bir yapıya sahiptir. Anket sonuçları hem yerel halk hem de ziyaretçiler için bunu göstermektedir. Kayısı sadece Malatya için değil ülkemiz ve dünya ticareti açısından da büyük bir öneme sahiptir. Bundan dolayı kayısı, üreticisi, perakendecisi, toptancısı ve ihracatçısı ile bir bütün olarak ele alınarak sorunların üstesinden gelinmeli; özel, resmi ve sivil toplum kuruluşları desteği ile sektörün gelişmesi için çaba sarf edilmelidir. Ülke içinde ve dışında tanıtım faaliyetlerine hız verilmelidir.

Kayısı sadece yaş ve kuru olarak tüketilen bir meyve değildir. Kayısı, meyve sularının ve meyve konsantrelerinin imalatında kullanılmasının yanında ayrıca pestil, bisküvi, reçel-marmelat, lokum, jöle, dondurma, çiklet, dolgu maddesi, pastacılık sektörü gibi alanlarda da kullanılmaktadır. Kayısı çekirdeği de yağ, kozmetik ve ilaç sanayiinde ve diyabetik özel amaçlı ürünlerde kullanılmaktadır (Sobutay,2003: 6) Malatya'nın marka değerinin artmasında Malatya kayısısı için yapılacak olan tanıtım çabaları büyük bir önem arz etmektedir.

Malatya denilince ikinci sırada akla gelen özellik gastronomidir. Gastronomi(yemek) bugün önemi gittikçe artan bir sektör haline gelmiştir. Yapılan ankette hem yerel halk hem de ziyaretçiler tarafından ikinci sırada yemek faktörünün gösterilmesi Malatya için büyük bir önem arz etmektedir. Günümüze kadar Malatya denilince akla sadece kayısı gelmekte idi. Ama bu anket sonuçları gastronomi faktörünün de Malatya için gittikçe önem arz eden bir unsur olduğunu ifade etmektedir. Malatya'nın yerel yemekleri (çorbaları, et yemekleri, köfteleri, içecekleri vb.) ile ilgili yapılacak olan çalışmalar, yöreye ait bazı yemeklerin tescil ettirilmesini sağlayabilecek ve zengin bir mutfak kültürünün de ortaya çıkmasına vesile olacaktır. Oteller, lokantalar, mesire yerleri gibi gastronomi kültürünün yaygın olduğu mekânlarda yöresel yemeklerin yapılmasının teşvik edilmesi, Malatya'nın yöresel yemekleri ile de adının anılmasını sağlayacaktır.

Yapılan ankette yerel halk, üçüncü sırada Malatya'nın misafirperver özelliğini ifade etmiştir. Bu özellik Malatya halkının hoşgörü, saygı ve sevgi gibi erdemlere fazlası ile sahip olduğunu göstermektedir.

Malatya'ya gelen ziyaretçilere, Malatya denilince üçüncü sırada akla gelen özellik sorulduğunda siyasetçi kavramını ifade etmişlerdir. Siyasetçi kavramı ile ifade ettikleri kişiler ise İsmet İnönü ve Turgut Özal'dır. Bu iki siyasetçi de Türk siyasi hayatının belli dönemlerine damgasını vurmuş şahsiyetlerdir. Her ikisi de uzun yıllar siyasetin içinde kalmış hem başbakanlık hem de cumhurbaşkanlığı yapmış kișilerdir. Bu siyasetçiler bugün yaşamıyor olsalar da Türk siyasi hayatına olan etkileri ve günümüze olan yansımaları tetkik edilmelidir.

Malatya'yı bölgedeki diğer illerden sırası ile farklı kılan üç özellik yerel halk için kayısı (\% 23,6), güvenlik $(\% 7,3)$, misafirperverlik $(\% 6,8)$ iken; ziyaretçiler için kayısı $(\%$ $17,5)$, misafirperver $(13,6)$, üçüncü sirada ise toplamda 
(\%12,3)'lük bir orana sahip olan çevre temizliği $(\% 4,01)$, tarihi mekânlar $(\% 4,01)$ ve gastronomi $(\% 4,01)$ gelmektedir.

Hem yerel halk hem de ziyaretçiler için Malatya'nın farkındalık oluşturan en önemli özelliğinin kayısı olması şehrin konumlandırılmasında büyük bir öneme sahiptir. Yeter ki bu konumlandırma şehrin paydaşlarının zihninde özel bir yere sahip olsun. Türkiye'nin doğu ve güney doğusunda güvenlik sorunlarının yaşandığı birçok il varken ülkenin doğusunda yer alan Malatya'da böyle bir sorunun yaşanmaması, halkın hoşgörü, saygı ve sevgi unsurlarına ziyadesiyle ile önem vermesi, bölgedeki birçok il ile kıyaslandığında Malatya'nın gelişme ve kendini ifade etme potansiyeline fazlası ile sahip olduğunu göstermektedir. Ayrıca ziyaretçiler çevre temizliğinin ve tarihi mekânların da şehrin olumlu imajına katkıda bulunacağını belirtmektedir.

Malatya'nın şehir imajı ile ilgili daha önce yapılmış olan çalıșmalar da bulunmaktadır. İnönü Üniversitesi İletişim Fakültesi Dekanı Prof. Dr. Metin Işık'ın koordinasyonunda 20 ilde 1067 kişi ile 'SSehirler ve İmajlar: Marka Şehir Olma Sürecinde Türkiye'de Malatya İmajı" konulu yüz yüze anket çalışması yapılmıştır (İnönü Üniversitesi, 2016).

Anket çalışmasına katılanların \%52,7'si erkek, \%47,3'ü kadınlardır. Araştırmaya katılanların \% 85'inin zihninde Malatya denilince olumlu bir çağrışım oluşmaktadır. Malatya denilince katılımcıların aklına ilk gelen özelliğin \%78,1 ile kayısı olduğu görülmüştür. İkinci özellik olarak $\% 9,2$ ile İnönü Üniversitesi gelmektedir. Katılımcıların \%26,3'ü Malatya'ya geldiğini ifade etmiştir. Malatya'nın Türkiye'nin hangi bölgesinde bulunduğu sorusuna katılımcılardan \%69,3'ü "Doğu Anadolu Bölgesi" şıkkını işaretleyerek doğru cevap vermişlerdir. Katılımcıların \%73,8'ine göre Malatya'nın en önemli değeri kayısıdır. Katılımciların \%45'ine göre Malatya modern bir şehir, \%28,5'ine göre Malatya bir sanayi şehri, \%55'ine göre Malatya temiz bir şehir, \%64,1'ine göre Malatya sakin bir şehir, \%55,6'sına göre Malatya güvenli bir şehir, \%40,5'ine göre ise Malatya ucuz bir şehirdir. Katılımcıların \%56,7'sine göre Malatya halkı dindar, \%61,5'ine göre Malatya halkı hoşgörülü, \%62,1'ine göre Malatya halkı sıcakkanlı, \%57,3'üne göre Malatya halkı yardımsever, \%42,9'una göre Malatya halkı girişimci, \%50,7'sine göre Malatya halkı çalışkan olarak değerlendirilmektedir. Katılımcıların \%25,9'u Malatya'yı yaşamak isteyeceği bir şehir olarak değerlendirmiştir.

'Şehirler ve İmajlar: Marka Şehir Olma Sürecinde Türkiye'de Malatya İmajı' konulu çalışma (İnönü Üniversitesi, 2016) ile bu çalışmanın örtüştüğü ifadeler şunlardır:

(i) Araştırmaya katılanların $(\% 78,1)$ 'i kayısının, Malatya'nın en önemli değeri olduğunu belirtmektedir. Bu çalışmada bu oran yerel halk için $(\% 82,1)$, ziyaretçiler için $(\% 80,7)$, olarak ifade edilmiştir.

(ii) Araştırmaya katılanların $(\% 61,5)$ 'i Malatya halkını hoşgörülü olarak değerlendirmiştir. Bu çalışmada anket sorularında Malatya'yı bölgedeki diğer illerden sırası ile farklı kılan üç özellik ziyaretçiler için 2. sırada Malatya halkı misafirperverdir (\% 13,6) ifadesi yer almıştır.

\section{Sonuç ve Değerlendirme}

Malatya'nın turizm potansiyelinin ortaya çıkarılması açısından şehrin sahip olduğu tarihi ve kültürel değerler ile anket çalışmasında elde edilen sonuçlar dikkate alındığında, aşağıdaki tavsiyeler söylenebilir:

(i) Şehrin konumlandırılmasında 'kayısı' büyük bir faktördür. Önemli olan kayısının şehrin tüm paydaşları tarafından sahiplenilecek şekilde zihinlere yerleştirilecek bir çalışmanın yapılmasıdır. Şehrin konumlandırılması turizm potansiyeli açısından farkındalık oluşturabilecektir.

(ii) Araştırma sonuçları kongre ve gastronomi turizmi gibi alanların yeterince değerlendirilmediğini göstermektedir. Şehrin turizm potansiyelini belirleme sürecinde araştırma sonuçlarından da yararlanılarak, özellikle bu alanların da içinde olduğu yeni bir destinasyon imaj çalışması yapılabilir. Reklam ve tanıtımın bu özelliklere göre yapılması halinde daha başarılı bir sonuç elde edilebilir.

(iii) Malatya'nın kayısısı, tarihi yapıs1, gastronomisi, misafirperverliği, güvenli bir şehir olması ve Malatya'da yetişen ünlüler (Turgut Özal, İsmet İnönü vb.) şehrin yeni bir logo tasarımı ve slogan çalışması için kullanılabilir. $\mathrm{Bu}$ durum şehrin turizm potansiyelinin zenginliğini ziyadesi ile etkileyebilir.

(iv) Malatya'nın destinasyon turizminin ortaya çıkarılmasında gastronomi önemli bir faktördür olarak karşımıza çıkmaktadır. Malatya'nın bu zengin gastronomi (yeme-içme) kültürünün sunulacağı yer ve sunuş şekli büyük önem arz etmektedir.

(v) Malatya'nın tarihi yapısı açısından birçok medeniyete ev sahipliği yaptığı tarihi bilgilerde de ifade edilmektedir. Anket sonuçlarına göre de bu konunun önem arz ettiği belirtilmiştir. Roma ve Bizans dönemlerinde önemli bir yerleşim merkezi olan Malatya'nın Battalgazi merkez ilçesindeki tarihi yapılar restore edilerek ve koruma altına alınarak ziyaretçilerin beğenisine sunulması turizmin canlanmasında daha da etkin rol alabilir.

(vi) Turizm destinasyonu ile ilgili çalışma yapan araştırmacıların her destinasyonun (il, bölge, ülke) benzer destinasyonlardan farklı olarak kendine has özellikleri olduğu bilinci ile hareket etmeleri halinde şehrin konumlandırılması ve turizm destinasyon pazarlaması alanında başarılarını artırabilirler.

\section{Kaynakça}

Akbulut, G. (2010). Malatya İlinde Nüfusun Eğitim Durumu, Atatürk Üniversitesi Sosyal Bilimler Enstitüsü Dergisi, 14(1), 115-132.

Akçi, Y., \& Uluışık, Ö. (2016). Marka Şehir Oluşturma: Şehirde Oturanların Değerlendirmeleri Üzerine Bir Uygulama (Adıyaman Örneği). Mustafa Kemal Üniversitesi Sosyal Bilimler Enstitüsü Dergisi, 13(34), 355-371.

Aslanova, K. (2013). Türkiye'de Sağlık Turizmi ve Sağlık Turizmi Hukuku. Avrasya Uluslararası Araştırmalar Dergisi, 3(3), 129-145. 
Aytaç, İ. (2015). Geleneksel Malatya Evleri Envanteri. Malatya: Malatya Büyükşehir Belediyesi Kültür A.Ş.Yayını.

Başıüyük, Ş. (2014). Malatya'nın Puslu Yılları. İstanbul: Beyan Yayınlar1.

Başıüyük, Ş. (2015). Saadet Şehri Malatya. İstanbul: Beyan Yayınları.

Burns, C., A., \& Bush, F. R. (2015). Pazarlama Araştırması. (Ed.) Fatma Demirci Orel. Ankara: Nobel Yayınları.

Ceylan, H. H. (2010). Yerel Kalkınma ve Rekabet Aracı Olarak Şehir Pazarlamasında Yatırımcıların Yatırım Destinasyon Tercih Yaplarının Belirlenmesi ve Uşak Tekstil Sektöründe Bir Uygulama. Doktora Tezi. Afyon: Afyon Kocatepe Üniversitesi.

Cohen, L. Manion, L., \& Morrison, K. (2007). Research Methods in Education. New York: Routledge.

Çağlar, A., \& Gülel F. E. (2015). Sağlık Hizmetlerinden Memnuniyet: Etkinlik ve Mekânsal Etkileşim Analizi. Journal of life Economics, (4), 29-58.

Çağl1, I. B. (2012). Türkiye'deki Yerel Kültürün Turizm Odaklı Kalkınmadaki Rolü: Gastronomi Turizmi Örneği. Yüksek Lisans Tezi. İstanbul: İstanbul Teknik Üniversitesi.

Çiçek, A. (2011). Malatya'da Meslek Yapısı ve Sosyal Hareketlilik. Doktora Tezi. Malatya: İnönü Üniversitesi.

Demirovic, D. (2016). Creating Brand Herzegovina As a Tourist Destination. Master Thesis. İzmir: Yaşar University.

Doğan, E., \& Çelik, H. (2015). Niyaz-i Misri'nin Tasavvuf ve Ehli-Beyt Anlayış1. Türk Kültürü ve Hacı Bektaş Veli Araştırma Dergisi, 76(2), 147-164.

Ergu, E. (2013). Malatya Karaciğer Nakil Merkezi Oluyor. (Erişim: 03.02.2017), http://www.gazetevatan.com/elifergu-563712-yazar-yazisi-malatya--karaciger-nakilmerkezi-oluyor/

Ertin, G. (1998). Tarım, Hayvancılık, Ormancılık. (Erişim 04.14.2016), http://w2.anadolu.edu.tr/aos/kitap/IOLTP/ 2291 /unite08.pdf

Gezer, İ., Özcan, Ş., Tuğrulca, O., Özbudak, K. vd. (2011). Malatya Vizyon 2023. Malatya: Bilsam Yayınları.

Gezer, İ., Polat,I., Tuncel, G., \& Akbiyık, N. (2013). Doğanşehir Gelecek Stratejileri Raporu. Malatya: Bilsam Yayınları.

Gök, A., \& Tuna, H. (2013). Turizm Pazarlaması Açısından Malatya İlinin Potansiyelinin Belirlenmesi. KMÜ Sosyal ve Ekonomik Araştırmalar Dergisi, 15(24), 01-11.

Gökalp, Z. D. (2009). Malatya Arkeoloji Müzesinde Bulunan Bizans Anonim Fosilleri. Anadolu Üniversitesi Sosyal Bilimler Dergisi, 9(1), 217-250.

Hoang, V. T. (2010). Urban Planning and the Place Marketing Model: An Application to Cities and Provinces in Viet Nam. Doctoral Thesis. Australia: Victoria University.
İlker, G. (2012). Türkiye'de Termal Turizme Yönelik Hizmet Veren Konaklama Isşletmelerinde Pazarlama Karması Elemanları: Örnek Bir Alan Araştırması. Doktora Tezi. Konya: Selçuk Üniversitesi.

İnönü Üniversitesi (2015). Tarihçe. (Erişim: 30.11.2015), http://inonu.edu.tr/tr/14/m?m=15.

İnönü Üniversitesi (2016). Marka Şehir Olma Sürecinde Malatya. (Erişim: 25.10.2016), http://basin.inonu.edu.tr /haber.php?id=1364\#.WOOZoqIlGUk

Karabacak, Z. İ. (2013). Yerel Dokusunu Yitirmekte Olan Bir Kent: Malatya. Turkish Studies, 8(5), 345-355.

Karagöz, M. (2013). Malatya'nın XVII. Ve XVIII. Asırlarda Ticari Hayatı. Inönü Üniversitesi Uluslararası Sosyal Bilimler Dergisi, 2(2), 1-28.

Kesriklioğlu, Z., \& Çiftlik, Z. (2011). Türk Siyasi Tarihinde Turgut Özal. Malatya: Malatya Belediyesi Kültür Yayınları.

Kılıç, İ. H. (2016). Malatya Çorbaları. Malatya Cegit Aktüel Kültür Sanat Spor Dergisi, 6(1), 60-61.

Kurtuluş, K. (1985). Pazarlama Araştırmaları. İstanbul: İşletme İktisadı Enstitüsü Yayınları.

Malatya Büyük Şehir Belediyesi (2015a). Malatya Kültür Envanteri. (Erişim: 10.02.2016), http://www.Malatya. bel.tr/icerik/45/479/Malatya-envanteri.aspx

Malatya Büyük Şehir Belediyesi (2015b). Stratejik Plan 2015-2019. Malatya: Malatya Büyük Şehir Belediyesi Yayını.

Malatya Ticaret ve Sanayi Odası (2014). Stratejik Plan (2014-2017). Malatya: Malatya Ticaret Odası Yayınları. (Erişim: 10.02.2016), http://www.malatyatso.org.tr/ assets/images/oda/sp2.pdf

Malatya Valiliği (2004). Sosyal, Kültürel ve Ekonomik Yönleri İle Malatya. (Erişim: 10.02.2016), https://www. csb.gov.tr/db/malatya/webmenu/webmenu1311.pd.

Malatya Valiliği (2011). Malatya İ Çevre Durum Raporu. (Erişim: 02.03.2016), http://www.csb.gov.tr/turkce/ dosya/ced/icdr2011/malatya_icdr2011.pdf

Malatya Valiliği (2013). Malatya Kent Rehberi: Malatya Kayısısı. Malatya: Malatya Valiliği Yayını.

Malatya Valiliği (2014). Il Gida Tarım ve Hayvancılık Müdürlüğü Birifing Dosyası. Malatya: Malatya Valiliği Yayını. (Erişim: 03.05.2016), http://malatya.tarim. gov.tr/Menu/16/Faaliyetlerimiz

Malatya Valiliği (2016). Turistik Tesisler. (Erişim: 15.07.2016), http://www.malatya.gov.tr/turistik-tesisler

Miličević, K. (2016). Destination Branding as a Destination Competitiveness Factor: Case of Croatia. Doctoral Dissertation. Slovenia: University of Ljubljana.

Nakip, M. (2006). Pazarlama Araştırmaları. Ankara: Seçkin Yayıncilık.

Rainisto S. (2003). Success Factors of Place Marketing: A Study of Place Marketing Practices in Northern Europe and the United States. Doctoral Dissertations. Helsinki: Helsinki University of Technology. 
Sağlık Bakanlı̆̆ı (2015). Sağllk İstatistikleri Yıllı̆̆ 2014. Ankara: Sentez Yayıncılık.

Sayım, F. (2007). Malatya İli Yerel Ekonomi Araştırma. Malatya: MİADAP Araştırma Planlama Grubu. https://doi.org/10.13140/RG.2.1.3855.4480

Sever, R. (2008). Malatya'daki Hava Kirliliğine Coğrafi Bakış. Doğu Coğrafya Dergisi, 13 (20), 59-76.

Sobutay, T. (2003). Kayısı Sektör Araştırması. İstanbul: İstanbul Ticaret Odası Dış Ticaret Şubesi Araştırma Servisi. (Erişim: 14.12.2015.), http://www.ito.org.tr/ Dokuman /Sektor/1-54.pdf

Taş, V. (2011). Kemal Sunal Filmleri. İstanbul: Esen Kitap.

Tatar T., Bayhan V., Tatar. H., \& Ersoy E. (2011). Malatya Imajı ve Turizm Rekreasyon Kaynakları Kullanıcılarının Profili ve Talepleri Araştırması Raporu. (Erişim: 29.04.2016), https://s3.amazonaws.com/academia.edu. documents/38206970/PKAD_TK_DESTEK_DOKUM AN_2_EK-4_MALATYA_ILI_ANKET_RAPORU .pdf?AWSAccessKeyId=AKIAIWOWYYGZ2Y53UL3 A\&Expires $=1521134020 \&$ Signature $=O 0 L A r H b 46 A N j$ DcUnPaTngLm5Zp4\%3D\&response-content-dispositi on=inline \%3B\%20filename\%3DBolge_-_Alt_Bolge_ Il_Olceginde_Peyzaj_Ka.pdf

Tuğrulca, O. (2013a). Malatya Tarih Kent ve Kültür (Neolitik Dönemden Osmanll Dönemine Kadar MÖ:7000-MS:1300). İstanbul: Malatya Belediyesi Kültür Yayınlar1.

Tuğrulca, O. (2013b). Malatya Tarih Kent ve Kültür (Osmanlı Dönemi 1300-1918). İstanbul: Malatya Belediyesi Kültür Yayınları.

Tuğrulca, O. (2013c). Malatya Tarih Kent ve Kültür (Cumhuriyet Dönemi 1918-2011). İstanbul: Malatya Belediyesi Kültür Yayınları.

TUİK (2015). Türkiye İstatistik Kurumu Malatya Bölge Müdürlüğü İstatistiklerle Malatya. (Erişim: 29.04.2016), http://www.malatya.gov.tr/kurumlar/malatya.gov.tr/Dos yalar/Menuler/\%C4\%B0statistiklerle\%20Malatya/2015 $\% 20$ Yili\%20Haziran\%20Ayi\%20Turkiye\%20I1\%20Sun umu.pdf

TUİK (2016a). Adrese Dayalı Nüfus Kayıt Sistemi Sonuçları, 2015. (Erişim: 17.04.2016), http://www.tuik.gov.tr /PreHaberBultenleri.do?id=21507

TUİK (2016b). Türkiye İstatistik Kurumu Malatya Bölge Müdürlüğ̈̈ Nisan 2016. (Erişim: 29.04.2016), http://www.malatya.gov.tr/istatistiklerle-malatya

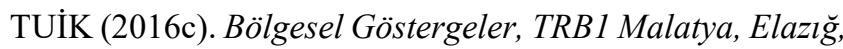
Bingöl, Tunceli. (Erişim: 02.11.2016), http://www.tuik.gov.tr/Kitap.do?metod=KitapDetay\&K T_ID=0\&KITAP_ID $=177$

TUİK (2016d). N Nüfusa Dayalı İstatistiki Bilgiler. (Erişim: 10.07.2016) http://www.tuik.gov.tr.

UNWTO (2017). Sustained growth in international tourism despite challenges. (Erişim: 03.02.2017) https://www.slovenia.info/uploads/dokumenti/raziskave/ unwto_barom17_01_january.pdf
Ünal, M. R. (2010). Kayısı Araştırma Raporu. Malatya: Fırat Kalkınma Ajansı.

Vatan, A. (2015). Destinasyon Pazarlaması Kapsamında Bilecik İli Turizminin Değerlendirilmesine Yönelik Paydaş Analizi. Doktora Tezi. Sakarya: Sakarya Üniversitesi.

Yatırım ve İşletmeler Genel Müdürlügüu (2016). Işsletme Belgeli Tesisler. Ankara: T.C. Kültür ve Turizm Bakanlığı Yatırım ve İşletmeler Genel Müdürlüğü. (Erişim: 10.07.2016), http://yigm.kulturturizm.gov.tr/ TR,9857/isletme-belgeli-tesisler.html

Yenen, M. (1939). Şehirlerimizin İmar Planı Tanzimine Doğru. Belediyeler Dergisi, 4(44). 